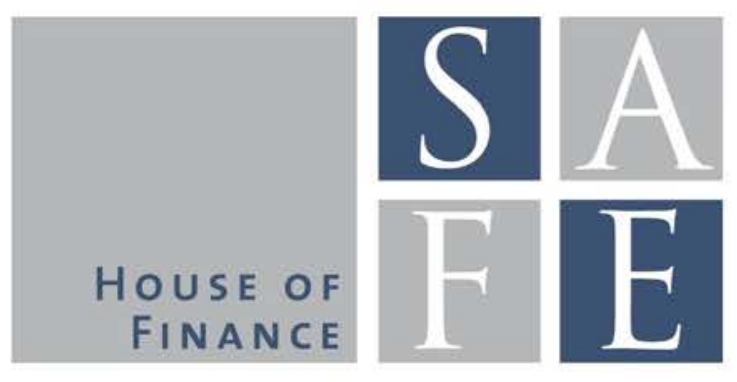

WORKING PAPER SERIES

Loriana Pelizzon - Matteo Sottocornola

\title{
The Impact of Monetary Policy Interventions on the Insurance Industry
}

SAFE Working Paper No. 204

SAFE I Sustainable Architecture for Finance in Europe A cooperation of the Center for Financial Studies and Goethe University Frankfurt 


\section{Non-Technical Summary}

Since 2008 Europe is facing a low and heterogeneous economic growth with peripheral countries still struggling to recover from pre-crisis periods. The prolonged low growth environment has been complemented by a contextual period of low inflation and ultra-low yields fostered by the expansionary monetary policy interventions adopted in particular by the ECB and the FED. As a matter of fact the conventional and unconventional interventions of the central banks aimed at contrasting the economic stagnation increased both in frequency and magnitude. The ECB is enforcing since 2013 a series of conventional and unconventional expansionary monetary intervention, including Quantitative Easing. These expansionary interventions, in addition to the welcomed stimulus on the economy, result in extremely low interest rates exacerbating the problems arising from the low yield environment.

The persistent low yield environment is heavily affecting the EU financial services industry and it is becoming a severe threat for the life insurers in terms of solvency and sustainability of their business models. From a policymakers perspective an increasing attention on the stability and profitability of life insurers is expressed by EIOPA and some National Competent Authorities that constantly rank the low yield environment as the major source of risk for the life insurers. Concerns are specifically addressed towards companies with a relevant outstanding portfolio of products entailing guaranteed rates of return and profit participation features. The lack of sufficiently remunerable rated assets on the market substantially reduce the capability for (re)insurers to match by a return and duration perspective the outstanding portfolio of guaranteed policies underwritten in high-yield years. ECB QE tend to exacerbate the scarcity of valuable assets on the market.

The academia deeply investigates both the effects of the low yields on (re)insurers and the effects of the monetary policy interventions on the markets. On the first topic the studies support the concerns on the vulnerability of the insurance industry to low interest rates with several studies. For what the impacts of central bank interventions are concerned a vast literature scrutinizes the role of the monetary policy announcements on asset pricing with room to be filled in the area of unconventional interventions in near-zero interest rate environments. All in all, if on the one hand there is a common understanding on the relation between monetary interventions, interest rate term structure, on the other hand the effect of unconventional expansionary monetary policy on the market in general and on insurers in particular does not provide conclusive elements, especially in a low or negative yields environment.

With this paper we aim at filling this gap by investigating the effect of the conventional and unconventional monetary policy intervention on the insurance industry with a twofold approach. At first we run an event study on the announcement date of the last ECB Quantitative Easing program. We scrutinize the cumulative abnormal return of a sample of 166 (re)insurers split into different subsamples according to size and geographical criteria comparing it with the behavior of the other market participants

Subsequently, with the aim of understanding the impact of the general enforced monetary policy strategy and not of a single event, we enlarge the scope of our analysis by investigating the effects on the markets in general and on insurers in particular, of a series of announcements made by the ECB and the Fed. To do so we replicate the approach proposed by Rogers et al. (2014) and Pericoli and Veronese (2016) analyzing how and to what extent the Central Banks announcements are signaled by the stock markets via changes in the term structure of the risk free rate. We apply the model on the same sample of (re)insures over a timeframe of 8 years split into 4 periods according to the economic cycles: i) tranquil period (01/01/2002 to $31 / 07 / 2007)$; ii) US sub-prime crisis (01/08/2007 to $31 / 12 / 2009$ ); iii) EU sovereign debt crisis (01/01/2010 to 31/05/2013) and iv) the low yield environment (01/06/2013 to $15 / 09 / 2015$ ). 
The event study suggests a moderate negative effect of the QE on the insurance industry. The different specifications we tested show how the outcomes of the event study are strongly dependent to the observation periods. Furthermore, we do not obtain statistically significant results for the subsample of the low yield environment. By applying the monetary policy surprise based model, we document how the effect of monetary policy interventions on interest rate in the announcement days changes over time and the subsequent impact of the expansionary monetary policy interventions on the market in general and on the insurance industry in particular. For the two periods from 2008 till 2013 we find that when the monetary policy announcement generates an immediate reduction in the interest rates, the stock market returns increases and the effect on the insurance industry is even stronger and positive. However, in the fourth period, when ECB started the QE program, the impact of monetary policy announcements on stock returns is not statistically significant. The two applied models return consistent results. The results are also the same if we compare the impact on the (re)insurance companies and other non-insurance listed companies Nevertheless this work shows how a single intervention extrapolated from the comprehensive strategy should be utilized with caution to estimate the effect of the monetary policy intervention on the market. For a robustness check we also perform the same analysis using insurance CDS data for the subsample of insurance companies of which the CDS price is available. The analysis shows that the pattern is confirmed and therefore our results are robust even for a smaller sample and using data from the CDS market.

We also investigate whether the characteristics of the (re)insurers matters for the impact of the unconventional monetary policy on insurance companies. We investigate to what extent the fundamentals of an insurer, namely the composition of the assets and liability side, are significant determinants for the reaction to monetary policy. Our analysis shows that the sensitivity is mainly driven by size and asset allocation and in particular by exposure to fixed income assets. None of the liability explanatory variables that we consider shows any significance. These results confirms that the peculiarities of the insurance companies are not extremely relevant to explain the impact of monetary policy on both the equity and the CDS price of (re)-insurance companies. 


\title{
The Impact of Monetary Policy Interventions on the Insurance Industry
}

\author{
Loriana Pelizzon* and Matteo Sottocornola ${ }^{\dagger}$
}

This version: March 2018

\begin{abstract}
This paper investigates the effect of the conventional and unconventional (e.g. Quantitative Easing - QE) monetary policy intervention on the insurance industry. We first analyze the impact on the stock performances of 166 (re)insurers from the last QE programme launched by the European Central Bank (ECB) by constructing an event study around the announcement date. Then we enlarge the scope by looking at the monetary policy surprise effects on the same sample of (re)insurers over a timeframe of 12 years, also extending the analysis to the Credit Default Swaps (CDS) market. In the second part of the paper by building a set of balance sheet-based indices, we identify the characteristics of (re)insurers that determine sensitivity to monetary policy actions. Our evidences suggest that a single intervention extrapolated from the comprehensive strategy cannot be utilized to estimate the effect of monetary policy intervention on the market. With respect to the impact of monetary policies, we show how the effect of interventions changes over time. Expansionary monetary policy interventions, when generating an instantaneous reduction of interest rates, generated movement in stock prices in the same direction till September 2010. This effect turned positive during the European sovereign debt crisis. However, the effect faded away in 2014-2015. The pattern is confirmed by the impact on the CDS market. With regard to the determinants of these effects, our analysis suggests that sensitivity is mainly driven by asset allocation and in particular by exposure to fixed income assets.
\end{abstract}

Keywords: Event study, monetary policy surprise, unconventional monetary policy, conventional monetary policy, insurance industry

JEL Classification: E44, E52, G14, G22

The content of this study does not reflect the official opinion of EIOPA. Responsibility for the information and views expressed therein lies entirely with the authors.

*Affiliation: Program Director Systemic Risk Lab and Chair of Law and Finance, Research Centre SAFE, Theodor W. Adorno Platz 3, Goethe University Frankfurt, D-60629 Frankfurt am Main, Germany and Full Professor in Economics, Ca Foscari University of Venice, Fondamenta San Giobbe 873, 30100 Venice, Italy. Contact: telephone +49 6979830047, e-mail pelizzon@finance.uni-frankfurt.de.

${ }^{\dagger}$ Affiliation: EIOPA, Westhafenplatz 1, D-60327 Frankfurt am Main., Germany, and Center of Excellence SAFE Sustainable Architecture for Finance in Europe, Theodor W. Adorno Platz 3, Goethe University Frankfurt, D-60629 Frankfurt am Main., Germany. Contact: telephone +49 69951119416, e-mail matteo.sottocornola@eiopa.europa.eu.

${ }^{\ddagger}$ The authors thank Marcello Pericoli for the helpful advice. The authors are grateful to Mario Bellia, Francesco Brunello, Jannic Cutura, Nicola Mano, and Silvia Dalla Fontana for excellent research assistance. We gratefully acknowledge research support from the Research Center SAFE, funded by the State of Hesse, initiative for research LOEWE and the financial support from the Deutscher Verein fuer Versicherungswissenschaft e.V. 


\section{Introduction and literature review}

To contrast the economic stagnation affecting Europe, the ECB has, since 2013, enforced a series of conventional and unconventional expansionary monetary interventions, including Quantitative Easing (the last Quantitative Easing (QE) was announced in January 2015). ${ }^{1}$ These expansionary interventions, in addition to their welcome stimulus of the economy, result in extremely low interest rates, exacerbating the problems arising from the low-yield environment.

This persistent low-yield environment heavily affects the EU financial services industry, and is becoming a severe threat for life insurers in terms of the solvency and sustainability of their business models. From a policymakers perspective, the European Insurance and Occupational Pensions Authority (EIOPA) has focused increasing attention on the stability and profitability of life insurers. These constantly rank the low-yield environment as the major source of risk for life insurers (EIOPA (2013), EIOPA (2014), EIOPA (2015)). Concerns are specifically addressed towards companies with a relevant outstanding portfolio of products entailing guaranteed rates of return and profit participation features. The lack of sufficiently remunerable rated assets on the market substantially reduce the capability for (re)insurers to match from a return and duration perspective, the outstanding portfolio of guaranteed policies underwritten in high-yield years. Concerns are shared by the national authorities overseeing markets that are traditionally active in saving products with minimum guaranteed returns, such as Germany. For instance, Deutsche Bundesbank (2013), from the 2013 stress test exercise, inferred that a persistent lowyield environment would heavily affect the solvency situation of German insurers. Moreover, the report concluded that under particularly adverse conditions, more than 30 per cent of the German life insurers would not meet Solvency II capital requirements by 2023. Comparable results are obtained by Berdin and Grndl (2015) in their model-based analysis on a stylized German life insurers solvency under the Solvency II regime. Wedow and Kablau (2011) analyzed the German market once more and reached less pessimistic conclusions. As a matter of fact, they empirically concluded that given the outstanding stock of guaranteed products, the solvency situation will be threatened only in extremely adverse scenarios. Nevertheless, the authors argue that a prolonged low-yield scenario would progressively worsen the solvency capability of insurance companies offering minimum guaranteed products. In the literature these kinds of products are commonly considered to be the most exposed to the drop in the interest rates. In particular, duration mismatches between assets and liabilities are considered to be the vulnerable point of these products, as qualitatively shown by Holsboer (2000) and theoretically expressed by $\mathrm{Li}$ and Wei (2013). In addition to the minimum guaranteed benefits, the profit participation component seems to cause trouble to insurers, as pointed out by Grosen and Lchte Jrgensen (2000) in their theoretical work. Profit distribution policies have been empirically investigated by Kling and Ru (2007a), both from a general and local perspective (Kling and Ru, 2007b). An additional element of vulnerability of the life insurers exposed to a persistent low-yield environment comes from surrender options potentially embedded in the contracts. Gatzert (2008) and Albizzati and Geman (1994) explain how, in periods of low profit sharing returns, policyholders

\footnotetext{
${ }^{1}$ See: ECB (2015).
} 
can opt for more attractive investments, enhancing the lapse risk. All these studies investigate the issue from a theoretical point of view using numerical simulation; with this work we aim to shed light on the empirical evidence related to stock market evaluation of the impact of unconventional monetary policies on the insurance industry. In fact, if on the one hand there is a common understanding regarding the relationship between monetary interventions and the interest rate term structure, on the other hand the effect on conventional and unconventional expansionary monetary policy on the market does not provide conclusive elements, especially in a low- or negative-yield environment. The impacts of the monetary policy on market valuations have been vastly investigated. Specifically, the role of monetary policy announcements on asset pricing is well documented (see Cook and Hahn (1998), Bernanke and Kuttner (2005), Ehrmann et al. (2011) and Ippolito et al. (2015), among others). However, the literature on Quantitative Easing and near-zero rates is still in its initial phase and has thus far mainly concentrated on measuring the effects of unconventional monetary policies on aggregates such as inflation and GDP (see Chen et al. (2012), Chung et al. (2010), Gambacorta and Peersman (2014) Gambacorta, Hofmann and Peersman (2014), and Kapetanios et al. (2012) amid others). A number of papers investigates the effect of unconventional policies on financial markets, with a focus on interest rates and equities in the U.S. and developed European countries. Instances of works in this area are Krishnamurthy and Vissing-Jorgensen (2011), D'Amico et al. (2012), King et al. (1991), Banerjee et al. (2014), Li and Wei (2013) and Pericoli and Veronese (2016). It is worth mentioning various studies that implement the event-study methodology in order to properly investigate the effects of unconventional monetary policies. Regarding the Eurozone, Briciu and Lisi (2015) have identified announcements that can be considered as complete surprises: they then simply added up the jumps in asset prices in short-time windows bracketing these announcements. Nevertheless, complete surprises do not account for market expectations. A way to bypass this issue is offered by Joyce et al. (2011), by normalizing data looking at the surveys periodically conducted by financial institutions, such as bank and insurances, with the purpose of measuring in a more realistic manner the market surprise in reaction to monetary policy announcements. However, due to the limited availability of surveys, this measure does not represent a viable alternative for many fields. A more effective approach, proposed by Rogers et al. (2014), has emerged as helpful; this involves measuring the effects of monetary measures on different asset prices relative to changes in government bond yields, and relies on a particular definition of monetary policy surprise, centered on the intraday changes in government bond yields right after the announcement. Despite these ample sources, no analysis has specifically focused on the insurance industry. We therefore focus our attention on how, and to what extent, the 2015 ECB QE and the convention and unconventional expansionary monetary policy strategy deployed by Central Banks impact the market performances of the (re)insurers, in terms of stock returns and Credit Default Swap (CDS) spreads. Our approach is twofold. The first part of the analysis identifies the effect of monetary policy interventions on (re)insurers, scrutinizing the reaction of stock prices to the policy actions of Central Banks. Initially, we elaborate on a simple event study based on a market model (Mackinlay, 1997) around the last ECB QE announcement (22 January 2015). Subsequently, we extend the anal- 
ysis to a broader sample of announcements, following the approach of Pericoli and Veronese (2016) who compare monetary policy announcement and non-announcement days in different sub-periods. In this second part, our paper builds on the latter intuition. The idea underlying this approach is that the periods are characterized by different "structural parameters", in the spirit of Rigobon (2003). Within these periods, estimates of impacts are obtained by separately pooling announcement and non-announcement days.

An additional step in the analysis of the impacts of monetary policy announcements consists of the identification of characteristics that drive the sensitivity of the companies to the events thereof. In the literature, the linkage between the impact of the change in interest rates on monetary policy decisions and the exposure of banks to different asset classes and to different businesses has been explored, both in the US and Europe. Arseneau (2017) shows that, in the US banking industry, the impact of monetary policy transmitted by a change in interest rates differs significantly, and much of this heterogeneity can be explained by cross-bank differences in the provision of liquidity services. In Europe, Ampudia and Van-den Heuvel (2017) empirically found that the composition of balance sheets is important in order to understand the effects of monetary policy decisions on banks. In particular, the two authors infer that banks with high deposit ratios are in general less sensitive to changes in interest rates, except when rates are low. To our knowledge, the analysis thereof is limited to the banking industry; therefore, in the second part of this work, we identify the determinants of sensitivity of (re)insurers to the ECB's monetary policy announcements based on the asset and liability composition of their balance sheet. We base our analysis on a logit regression, using the sensitivity of the (re)insurers to monetary policy interventions as a dependent variable, and a set of balance sheet-based indices approximating asset allocation and liability exposures as regressors.

The paper is structured in five sections. The introduction provides a review of the main relevant studies and presents the overall content of the study. In Section 2 and 3, we present the applied methodology and describe the utilized market-based and balance sheet-based datasets, respectively. Section 4 summarizes the empirical evidence of the effect of monetary policies on the insurance industry, and the determinants of the sensitivity of (re)insurers to the events thereof. The article concludes with the presentation of the main findings and further implications (Section 5).

\section{Methodology}

Our analysis encompasses two steps:

i we investigate the effects of conventional and non-conventional monetary policy interventions on the stock prices of a set of listed companies selected from different industries and different geographical areas (monetary policy impact analysis);

ii we then empirically identify the main determinants, at the balance sheet level, of the sensitivity of European (re)insures to the monetary policy actions of the ECB (analysis of the determinants) 


\subsection{Monetary Policy Impact Analysis}

To evaluate the effect of non-conventional monetary policy interventions enforced by the ECB, we focused on the QE program launched on the $22^{\text {nd }}$ of January 2015. More specifically, we designed an event study based on a market model around the announcement of the QE program. The Cumulative Abnormal Returns of insurers are computed against different samples in order to insulate the effect of the $\mathrm{QE}$ on the broad insurance market and on a set of subsamples defined according to geographical areas and sizes and in terms of total assets. We split the full sample based on geographical perspective into: i) US (re)insurers, ii) EU (re)insurers, iii) EMU (re)insurers, and iv) EU non EMU (re)insurers. Size-wise, we dissected the sample into big and small (re)insurers. It is worth noting that in this article we utilize the notation "big and small" in a relative manner. The sample includes large listed (re)insurers; nevertheless, to understand whether and to what extent size acts as determinant of the impacts of monetary policy intervention on insurers, we use the following divide: a threshold of EUR 50bn, used by the Financial Stability Board (FSB) and the International Association of Insurance Supervisors (IAIS) as a size criterion to identify G-SII insurers (IAIS (2016)). We computed, for each group, the Cumulative Abnormal Returns (CAR) around the announcement date, using a twoday event window as in Chen et al. (2012) as follows: ${ }^{2}$

$$
C A R_{i, t}=\sum_{j=1}^{t} A R_{i, j}
$$

where $i$ represents the institution and $j$ represents the time. The Abnormal Return (AR) of an institution $\mathrm{i}$ is computed according to equation (1).

$$
A R_{i, t}=O R_{i, t}-I R_{i, t}
$$

where the OR expresses the observed market return of the institution i, whereas IR expresses the implied return of the same institution. We compute implied returns on the (re)insurer $i$ in an estimation window from 26 August, 2013 to 20 January, 2015, according to equation (3).

$$
I R_{i, t}=\hat{\beta}_{i} \times O R_{i, t}
$$

where $\hat{\beta}_{i}$ is derived via Ordinary Least Squares (OLS) according to equation (4):

$$
\operatorname{Return}_{i, t}=\alpha_{i}+\beta_{i} \times \text { market }_{t}+\epsilon_{i, t}
$$

In the second part of the monetary policy impact analysis, in order to identify the causal relationship of monetary policy, we estimated an ordinary least squares regression of daily returns of(re)insurance companies on monetary policy surprises. Based on the fact that in the first instance, conventional and unconventional monetary policies affect the risk-free rate term structure, we define, according to Bernanke and Kuttner (2005) and Rogers et al. (2014), the

\footnotetext{
${ }^{2}$ The use of a longer window does not allow insulation of the effect of the analyzed event, as other elements may generate movements in stock prices.
} 
monetary policy surprise as the linear combination of changes on the overall term structure of interest rates. We then estimate the impact of the monetary policy surprise on the market returns of a panel of listed companies via OLS regressions, according to equation (5).

$$
\Delta y_{t}=\alpha+\beta \times \Delta R F R_{t=t_{a F E D}}^{F E D}+\gamma \times \Delta R F R_{t=t_{a E C B}}^{E C B}+\sum_{j} \phi_{j} \times X_{t, j}+u_{t}
$$

where $\Delta y_{t}$ is the change in the market return, $\Delta R F R_{t=t_{a F E D}}^{F D}$ and $\Delta R F R_{t=t_{a E C B}}^{E C B}$ are the FED and ECB monetary policy surprises defined as the first principal component factor PCA of the changes in 1-year, 2-year, 5-year, 7-year, and 10-year zero-coupon interest rates. ${ }^{3}$ In line with Pericoli and Veronese (2016), we used a set of control variables represented by $X_{t, j}$, namely the US Citi Economic Surprise Index (CESI), the Euro-area CESI, and the VIX. Equation (5) is estimated only around, but close to, $E C B\left(t=t_{a E C B}\right)$ or $F e d\left(t=t_{a} F E D\right)$ announcement days, split into five periods as follows.

$1^{\text {st }}$ from 6 September 2004 to 15 June 2008. We define this as a tranquil period characterized by conventional monetary policies conducted by both the ECB and the Fed. The interest rates in this period reported a general increasing trend, characterized, however, by some sharp drops.

$2^{\text {nd }}$ from 1 September 2008 to 31 August 2010. This is the period of the US sub-prime crisis and its subsequent global spillover. The Troubled Asset Relief Program (TARP) process and conventional and unconventional monetary policies (QE1 announced in November 2008 and ceased in March 2010) enforced by the Fed reduced US interest rates to near zero. In October 2008, the ECB began a progressive reduction of interest rates to a near-zero level, complemented by unconventional policies such as Long-Term Refinancing Operations (LTRO), announced in May 2009, and the Asset Purchases Programme (APP). Yield curves began a constant decrease, which was more pronounced for short-term maturities.

$3^{\text {rd }}$ from 1 September 2010 to 30 June 2012. The focus moved from the US to Europe. The period is characterized by severe tensions on the EURO, originating from speculative attacks to the currency and from the sovereign debt crisis of the peripheral countries of the Euro area. The near default of Greece represents the peak of this crisis. The ECB reaction was anticipated in the Whatever it takes speech of President Draghi and enforced by conventional monetary policy interventions (reduction of interest rate on deposit facilities to $0 \%$ ) and an unconventional monetary policy intervention (the launch of Outright Monetary Transactions - OMT). In order to combat the US economy downturn, the Fed proceeded along the path of conventional expansionary monetary policy complemented by unconventional monetary policies, launching the QE2 in November 2010 and the QE3in September 2012. Yields reacted with a high volatile general decrease, with the shorter maturities reaching, for the first time, the "zero level" in the period of observation.

\footnotetext{
${ }^{3}$ For the EU, we utilize the zero-coupon interest rate implied in government bonds, irrespective of their rating (ECB computation). For the US, we utilized the FED zero-coupon rate.
} 
$4^{\text {th }}$ from 1 July 2012 to 31 December 2013. The Euro sovereign debt crises reached an end, thanks to ECB interventions, leaving the markets with somewhat stable yields over the period, and around the zero for the shortest maturities up to $2 \%$ for 10 -year maturities.

$5^{\text {th }}$ from 1 January 2014 to 20 February 2017: The low-yield environment is the key topic to be mentioned. In order to contrast the prolonged stagnation of the economy in the euro area and to fulfill its mandate of keeping inflation close to $2 \%$, the ECB launched the Quantitative Easing program in April 2014, which was then further extended in 2015. Targeted longer-term refinancing operation (TLTRO) initiatives complemented the set of enforced unconventional monetary policies. Interest rates on deposit facilities turned negative from June 2014 onwards. In the US, the recovery of the economy led to the first increase in the Fed Funds rate at the end of 2015 (outside our period of observation).

The five periods and the yield movements are reported in figure 1 which depicts the term structure of the Euro Area risk free rates for the maturities used to compute the PCA and the decomposition of the 5 periods (vertical lines).

Figure 1: ECB risk-free rate term structure 1, 2, 5, 7, 10-year maturity.

Yield curve spot rate - 1, 2, 5, 7, 10-year maturity - Government bond, nominal, all issuers whose rating is triple A - Euro area (changing composition). Vertical lines identify the periods. Source: ECB.

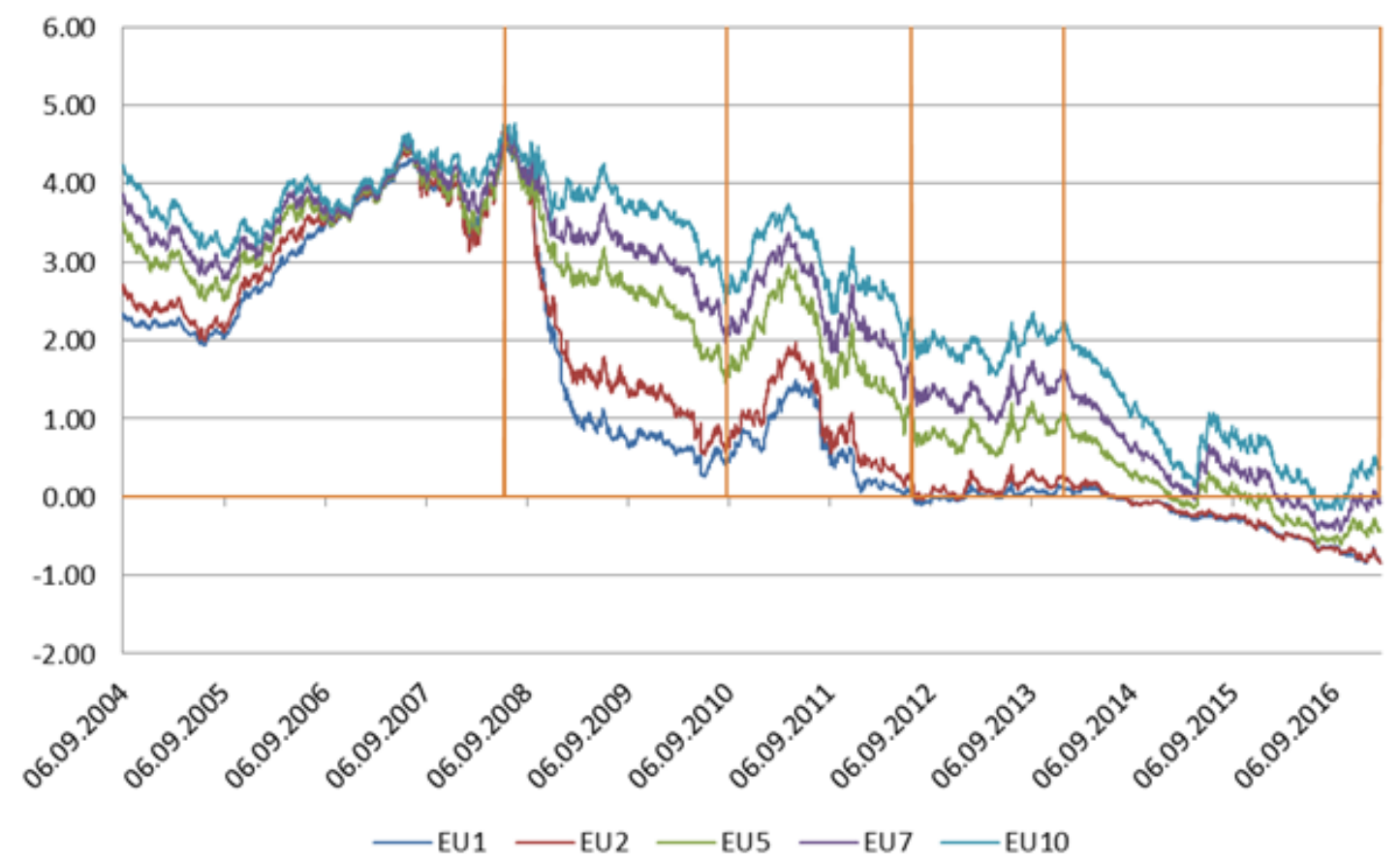

In order to check potential behavioral implications driven by the attempt of the market to anticipate or delay potential reactions to monetary policy announcements by the Central Banks, we tested the regression displayed in equation 5, not only on the day of announcement but also on a 3-day moving window around the day of announcement. 
This specification allows the investigation of whether conventional and unconventional monetary policies have been effective over time in fostering favorable conditions for (re)insurers when policy rates were stuck at the zero lower boundary, and if their transmission, operated through a decrease in term premiums, benefit the insurance industry. ${ }^{4}$

We also investigated the impact of monetary policy intervention on different markets. To that end, we applied the monetary policy surprise framework defined to assess the impacts on equity returns, namely the OLS model displayed in 5 , and the split of the time frame in equation 5 periods as depicted in Figure 1 to the CDS market. Against this background, the CDS-based specification of equation 5 is:

$$
\Delta C D S_{t}=\alpha+\beta \times \Delta R F R_{t=t_{a F E D}}^{F E D}+\gamma \times \Delta R F R_{t=t_{a E C B}}^{E C B}+\sum_{j} \phi_{j} \times X_{t, j}+u_{t}
$$

where $\triangle C D S_{t}$ is the first difference of the CDS spreads observed in the market at time $t$. The set of regressors and their definitions are unchanged with respect to equation 5 . The specification was tested in 3-day windows centered around the day of announcement.

\subsection{Analysis of the determinants}

In the analysis of determinants, we scrutinized whether the asset and liability structure might explain the higher or lower sensitivity of a (re)insurance undertaking to monetary policy interventions. Changes in yields in general, and in the reference risk-free rate in particular have impacts on both sides of the balance sheet of a (re)insurer. In fact, independent of the regulatory regime, the economic valuation of assets and the best estimates backing the provisioning reflect the market yield regime. The impact of a change in risk-free rates is even more relevant in a full market-based regulatory framework such as Solvency II, where technical provisions are computed by discounting future cash flows of the outstanding policy portfolio at the Risk-Free Rate (European Parliament and of the Council of 25, 2009). Against this background, we define a set of indicators aimed at representing the main characteristics of a company in terms of undertaken business and asset allocation (ref. Table 1).

\footnotetext{
days.

${ }^{4}$ Windows tested: -2 days, announcement day; -1 day, announcement day, +1 day; announcement day, +2
} 
Table 1: Balance Sheet Variables:

the table provides details on the list of variables used as regressors in the Logit. Balance sheet items are named according to the SNL Financial definition.

\begin{tabular}{lc}
\hline Variable & Definition \\
\hline Size & $\ln ($ Tangible Assets $)$ \\
Fixed Income Assets & $\frac{\text { Total Debt Instruments }}{\text { Tangible Assets-Separate Account Assets }}$ \\
Equity Assets & $\frac{\text { Total Equity Instruments }}{\text { Tangible Assets-Separate Account Assets }}$ \\
Cash and Equivalent & $\frac{\text { Cash \& Cash Equivalents }}{\text { Tangible Assets-Separate Account Assets }}$ \\
Non-Insurance Activities & $\frac{\text { Reserves for Insurance Contracts-Unit Linked Insurance) }}{\text { Total Liabilities-Separate Account Liabilities }}$ \\
LifeBusiness ${ }^{\text {EU }}$ & $\frac{\text { Lifeandhealthinsurancereserves }}{\text { TotalPolicyReserves }}$ \\
LifeBusiness & $\frac{\text { Lifeandhealthinsurancereserves }}{\text { TotalPolicy Reserves }}$ \\
Unit-Linked Business & $\frac{\text { Separate Account Liabilities }}{\text { Total Liabilities }}$
\end{tabular}

In order to test the relationship between defined balance-based indicators and sensitivity to monetary policy intervention, we ran a panel regression on the set of European (re)insurers on the five periods of observations. Specifically, we ran a Logit regression for each European company using as dependent a dummy variable defined on the coefficient of the regressor $\Delta R F R_{t=t_{a E C B}}^{E C B}$ obtained via equation 5, as follows:

$$
S L[01]^{i}= \begin{cases}1, & \text { if } p<0.1 \% \\ 0, & \text { otherwise }\end{cases}
$$

We use as the regressor set, the set of defined balance sheet items.

The baseline for the $i^{\text {th }}$ (re)insurer follows:

$$
S L[01]_{t}^{i}=\alpha+\sum_{j} \beta_{j} \times X_{j, t}^{i}+\gamma \times \text { dividendpayout }+\epsilon_{t}^{i}
$$

where $X_{j}$ includes the set of balance sheet indices reported in Table 1.

The contributions we expect from the indices thereof are strictly related to the characteristics of the different activities undertaken by the (re)insurers. It is worth noting that here we are using the word activity in a broad sense, namely including both the type of underwritten contract (e.g., life, non-life, non-traditional insurance activities) and the investment strategy enforced to back liabilities.

More specifically, we expect that the sensitivity of a (re)insurer to monetary policy intervention would be primarily driven by its asset allocation, particularly from its exposure to fixed income assets and equity assets. In particular, we expect that high exposure to fixed income 
assets, the value of which is directly influenced by the level of the risk-free rate, would be associated with high sensitivity (Hp.1).

Given that insurance is a liability-driven business where assets are primarily used to back the obligations of (re)insurers towards their policyholders, we also expect that the composition of the portfolio of liabilities plays a role in sensitivity to the monetary policy actions. A company more exposed to the life business, traditionally characterized by long-term liabilities, shall be more prone to shocks to yields, than a company active in the non-life business, which is usually based on yearly contracts, the price of which is adjustable at the same frequency (Hp.2). We also expect that engagement in non-traditional insurance activities, which usually implies maturity transformation-based products, might play a role ( $H p .3)$.

Being well aware that the interactions between assets and liabilities is of utmost importance to determine the exposure of a (re)insurer to fluctuations in market yields, we were keen to test the contribution of the duration mismatch between the assets and liabilities of (re)insurers. However, i) the scarce availability of data at sufficient level of granularity, and ii) the huge debate on how to calculate the duration of the (re)insurers portfolios encompassing optionalities embedded in both sides the assets (e.g., derivatives used for hedging purpose) and liabilities (e.g., profit participation-related benefits) prevent us from using these metrics in this paper.

In order to cope with mismatching between balance sheet reporting, which is available on a yearly basis, and the extension of the period that we defined for the monetary policy surprise analysis, we matched each of the five periods with the average figures disclosed by (re)insurers in balance sheets reported during the corresponding time frame, as reported in Table 2.

Table 2: Balance Sheet aggregation:

the table provides the approach used to aggregate the balance sheets in oder to match the five periods used in the monetary policy impact analysis.

\begin{tabular}{ccc}
\hline Period & Reference window & Balance sheet \\
\hline 1 & 6.9 .04 to 15.6 .08 & 2003 to 2007 \\
2 & 16.6 .08 to 31.8 .10 & $2008-2009$ \\
3 & 1.9 .10 to 30.6 .12 & $2010-2011$ \\
4 & 1.7 .12 to 31.12 .13 & $2011-2012$ \\
5 & 1.1 .14 to 20.2 .17 & 2013 to 2016 \\
\hline
\end{tabular}

\section{Dataset}

\subsection{Monetary Policy Impact Analysis}

We conducted the event study on a panel of 96 US and 70 European listed insurers, selected from among the largest in term of total assets. ${ }^{5}$ Data consist of the Total Return Index and market capitalization, retrieved via Thomson Reuters Datastream ${ }^{\circledR}$ of the (re)insurers over a time window of 370 trading days from August 26, 2013 to January 24, 2015. We used as an esti-

\footnotetext{
${ }^{5}$ Total assets reference date: year-end 2014. Data retrieved via SNL Financial ${ }^{\circledR}$.
} 
mation panel a set of indices for each geographical area containing all relevant listed companies, namely excluding all the small caps and the (re)insurers encompassed in our panel (i.e. only the largest companies that jointly account for $80 \%$ of the total market capitalization were used to compute country level market indices). Additionally, we remove all insurance companies and all companies that had less than 120 active trading days in any year. Based on end-year market capitalization figures, we computed weighted country market returns. We then built a set of country-based indices based on the market capitalization of the companies in order to scrutinize the effect of the QE $i$ ) at the European and US level, and ii) at the country level. Additionally, we split the sample according to the size of the insurers in order to understand whether and to what extent size acts as a determinant of the impact of monetary policy intervention on insurers. Table 3 provides details of the sample of (re)insurers.

Table 3: Descriptive Statistics (Event Study).

This table reports the summary statistics for the Total Return Index (TR) of the (re)insurers included in the different samples for the period from 26.08.2013 to 20.01.2015. Subsamples were created according to geography and size. Data were downloaded from Thomson Reuters Datastream ${ }^{\circledR}$ on 08 June 2015.

\begin{tabular}{lccccc}
\hline \multicolumn{1}{c}{ Sample } & Obs (\#) & Mean (\%) & Std. Dev. (\%) & Min (\%) & Max (\%) \\
\hline All companies & 166 & -0.90 & 6.80 & -71.20 & 19.30 \\
US companies & 96 & -1.50 & 8.10 & -71.20 & 19.30 \\
EU companies & 55 & 0.10 & 3.50 & -8.70 & 12.70 \\
EMU companies & 29 & -0.10 & 3.60 & -8.70 & 9.80 \\
EU non EMU companies & 26 & 0.40 & 3.40 & -3.80 & 12.70 \\
Big companies & 41 & -1.00 & 3.40 & -15.10 & 3.00 \\
Small companies & 125 & -0.80 & 7.60 & -71.20 & 1.73 \\
\hline
\end{tabular}

For the second part of our analysis, we regressed the stock returns of the (re)insurers based on the change in the risk-free rate term structure during the monetary policy days defined according to scheduled and unscheduled central bank board meetings, as well as on those days when relevant news on monetary policies were disclosed (Table 4 displays the summary statistics of the returns). ${ }^{6}$

The comparison of the stock returns during monetary policy days and other days provides heterogeneous outcomes. In the first two periods, the average values of the stock returns on the monetary policy days of the ECB and FED were lower than the values observed on "other days". The situation changed in the third period where higher returns are associated with monetary policy days. Values revert again in periods 4 and 5 .

\footnotetext{
${ }^{6}$ The full list of monetary policy days divided between US and EU is provided in Appendix A.6 and extend the one from Pericoli and Veronese (2016) paper. The lists are divided into two periods of observation, with the oldest slots only reporting scheduled meetings and the more recent ones that complement scheduled meetings with unscheduled meetings and relevant speeches.
} 
Table 4: Descriptive Statistics (Market returns).

The table reports summary statistics of the total return of stocks of the insurance companies included in the sample. Statistics are reported for ECB announcement days, FED

announcement days, and other days in the observation window.

\begin{tabular}{|c|c|c|c|c|c|c|c|c|c|c|c|c|c|c|c|}
\hline \multicolumn{16}{|c|}{ Period 1 - 6.9.04 - 15.6.08 } \\
\hline & \multicolumn{5}{|c|}{ ECB Announcement days } & \multicolumn{5}{|c|}{ Fed announcement days } & \multicolumn{5}{|c|}{ Other days } \\
\hline$\Delta y(\%)$ & Obs & Mean & Std. Dev. & Min & $\operatorname{Max}$ & Obs & Mean & Std. Dev. & Min & $\operatorname{Max}$ & Obs & Mean & Std. Dev. & Min & $\operatorname{Max}$ \\
\hline ALL & 155 & 0.033 & 0.351 & -1.364 & 1.842 & 155 & 0.238 & 0.457 & -0.980 & 1.978 & 155 & 0.056 & 0.108 & -0.284 & 0.942 \\
\hline $\mathrm{EU}$ & 51 & -0.089 & 0.306 & -1.364 & 0.565 & 51 & -0.001 & 0.341 & -0.980 & 1.449 & 51 & 0.072 & 0.065 & -0.027 & 0.296 \\
\hline EMU & 29 & -0.003 & 0.220 & -0.433 & 0.565 & 29 & 0.034 & 0.352 & -0.647 & 1.449 & 29 & 0.085 & 0.076 & 0.000 & 0.296 \\
\hline EU non EMU & 22 & -0.202 & 0.367 & -1.364 & 0.374 & 22 & -0.048 & 0.328 & -0.980 & 0.539 & 22 & 0.055 & 0.041 & -0.027 & 0.155 \\
\hline US & 90 & 0.082 & 0.314 & -0.771 & 0.935 & 90 & 0.376 & 0.473 & -0.967 & 1.978 & 90 & 0.041 & 0.124 & -0.284 & 0.942 \\
\hline
\end{tabular}

\begin{tabular}{|c|c|c|c|c|c|c|c|c|c|c|c|c|c|c|c|}
\hline \multicolumn{16}{|c|}{ Period 2 - 16.6.08 - 31.8.10 } \\
\hline & \multicolumn{5}{|c|}{ ECB Announcement days } & \multicolumn{5}{|c|}{ Fed announcement days } & \multicolumn{5}{|c|}{ Other days } \\
\hline$\Delta y(\%)$ & Obs & Mean & Std. Dev. & Min & $\operatorname{Max}$ & Obs & Mean & Std. Dev. & Min & Max & Obs & Mean & Std. Dev. & Min & Max \\
\hline ALL & 156 & -0.621 & 0.772 & -2.816 & 1.890 & 156 & 0.207 & 0.790 & -2.536 & 3.349 & 156 & 0.079 & 0.228 & -0.173 & 2.451 \\
\hline $\mathrm{EU}$ & 49 & -0.387 & 0.449 & -1.209 & 1.144 & 49 & 0.065 & 0.509 & -0.880 & 1.249 & 49 & 0.015 & 0.080 & -0.173 & 0.162 \\
\hline EMU & 27 & -0.460 & 0.506 & -1.209 & 1.144 & 27 & -0.066 & 0.445 & -0.817 & 0.818 & 27 & -0.009 & 0.067 & -0.162 & 0.094 \\
\hline EU non EMU & 22 & -0.297 & 0.360 & -0.902 & 0.302 & 22 & 0.227 & 0.545 & -0.880 & 1.249 & 22 & 0.045 & 0.087 & -0.173 & 0.162 \\
\hline US & 93 & -0.754 & 0.878 & -2.816 & 1.890 & 93 & 0.286 & 0.927 & -2.536 & 3.349 & 93 & 0.116 & 0.283 & -0.100 & 2.451 \\
\hline
\end{tabular}

\begin{tabular}{|c|c|c|c|c|c|c|c|c|c|c|c|c|c|c|c|}
\hline \multicolumn{16}{|c|}{ Period 3 - 1.9.10 - 30.6.12 } \\
\hline & \multicolumn{5}{|c|}{ ECB Announcement days } & \multicolumn{5}{|c|}{ Fed announcement days } & \multicolumn{5}{|c|}{ Other days } \\
\hline$\Delta y(\%)$ & Obs & Mean & Std. Dev. & Min & Max & Obs & Mean & Std. Dev. & Min & Max & Obs & Mean & Std. Dev. & Min & Max \\
\hline ALL & 160 & 0.225 & 0.464 & -1.687 & 1.838 & 160 & 0.369 & 0.874 & -2.787 & 8.275 & 160 & 0.054 & 0.115 & -0.687 & 0.694 \\
\hline $\mathrm{EU}$ & 52 & 0.311 & 0.489 & -1.687 & 1.118 & 52 & 0.101 & 0.562 & -2.787 & 0.852 & 52 & -0.005 & 0.130 & -0.687 & 0.148 \\
\hline EMU & 30 & 0.273 & 0.552 & -1.687 & 1.118 & 30 & 0.057 & 0.675 & -2.787 & 0.852 & 30 & -0.040 & 0.155 & -0.687 & 0.100 \\
\hline EU non EMU & 22 & 0.363 & 0.396 & -0.515 & 1.032 & 22 & 0.160 & 0.365 & -0.648 & 0.784 & 22 & 0.044 & 0.060 & -0.099 & 0.148 \\
\hline US & 93 & 0.126 & 0.430 & -1.436 & 1.838 & 93 & 0.561 & 0.999 & -1.274 & 8.275 & 93 & 0.090 & 0.100 & -0.236 & 0.694 \\
\hline
\end{tabular}

\begin{tabular}{|c|c|c|c|c|c|c|c|c|c|c|c|c|c|c|c|}
\hline \multicolumn{16}{|c|}{ Period 4 - 1.7.12 - 31.12.13 } \\
\hline & \multicolumn{5}{|c|}{ ECB Announcement days } & \multicolumn{5}{|c|}{ Fed announcement days } & \multicolumn{5}{|c|}{ Other days } \\
\hline$\Delta y(\%)$ & Obs & Mean & Std. Dev. & Min & Max & Obs & Mean & Std. Dev. & Min & Max & Obs & Mean & Std. Dev. & Min & Max \\
\hline ALL & 169 & 0.168 & 0.587 & -3.993 & 2.445 & 170 & 0.114 & 0.873 & -6.358 & 4.912 & 170 & 0.158 & 0.281 & -0.476 & 3.163 \\
\hline $\mathrm{EU}$ & 56 & 0.110 & 0.510 & -2.415 & 1.594 & 56 & 0.125 & 0.752 & -1.175 & 4.912 & 56 & 0.118 & 0.113 & -0.261 & 0.352 \\
\hline EMU & 31 & 0.113 & 0.630 & -2.415 & 1.594 & 31 & 0.167 & 0.959 & -1.175 & 4.912 & 31 & 0.130 & 0.107 & -0.148 & 0.352 \\
\hline EU non EMU & 25 & 0.105 & 0.314 & -0.724 & 0.617 & 25 & 0.073 & 0.373 & -0.805 & 0.805 & 25 & 0.104 & 0.120 & -0.261 & 0.224 \\
\hline US & 98 & 0.216 & 0.658 & -3.993 & 2.445 & 99 & 0.118 & 0.985 & -6.358 & 4.382 & 99 & 0.187 & 0.356 & -0.476 & 3.163 \\
\hline
\end{tabular}

\begin{tabular}{|c|c|c|c|c|c|c|c|c|c|c|c|c|c|c|c|}
\hline \multicolumn{16}{|c|}{ Period 5 - 1.1.14 - 20.2.17 } \\
\hline & \multicolumn{5}{|c|}{ ECB Announcement days } & \multicolumn{5}{|c|}{ Fed announcement days } & \multicolumn{5}{|c|}{ Other days } \\
\hline$\Delta y(\%)$ & Obs & Mean & Std. Dev. & Min & Max & Obs & Mean & Std. Dev. & Min & Max & Obs & Mean & Std. Dev. & Min & $\operatorname{Max}$ \\
\hline ALL & 184 & 0.173 & 0.577 & -2.292 & 4.310 & 184 & 0.312 & 0.714 & -1.621 & 6.646 & 184 & 0.507 & 5.703 & -0.166 & 77.283 \\
\hline $\mathrm{EU}$ & 61 & 0.271 & 0.403 & -0.714 & 1.475 & 61 & 0.175 & 0.446 & -1.621 & 1.884 & 61 & 0.050 & 0.063 & -0.059 & 0.318 \\
\hline EMU & 33 & 0.356 & 0.425 & -0.524 & 1.475 & 33 & 0.075 & 0.463 & -1.621 & 1.135 & 33 & 0.042 & 0.066 & -0.059 & 0.318 \\
\hline EU non EMU & 28 & 0.171 & 0.356 & -0.714 & 1.023 & 28 & 0.293 & 0.403 & -0.474 & 1.884 & 28 & 0.060 & 0.059 & -0.054 & 0.269 \\
\hline US & 106 & 0.121 & 0.681 & -2.292 & 4.310 & 106 & 0.386 & 0.867 & -0.444 & 6.646 & 106 & 0.844 & 7.511 & -0.095 & 77.283 \\
\hline
\end{tabular}

Furthermore, we replicated the analysis of the first difference of the CDS spreads of 43 (re)insurers (descriptive statistics displayed in Table 5. In the first three periods of observation, the average change in CDS spreads was positive during the announcement days, and larger on non-announcement days. This pattern was not observed in periods 4 and 5 . The CDS market shows a consistent pattern with respect to the stock market, specifically, a decrease in stock performance is associated with an increase in CDS spreads. It worth noting that the sample of (re)insurers with a sufficiently extended time series of traded CDS is materially smaller (43 entities: 5 EU, 26 US e 2 NON-EU) compared to the sample used for the stock return analysis (166 entities). 
Table 5: Descriptive Statistics (CDS spreads - first difference).

The table reports the summary statistics of the first differences in the CDS spreads of the insurance companies included in the sample. Statistics are reported for ECB announcement days, FED announcement days, and other days in the observation window.

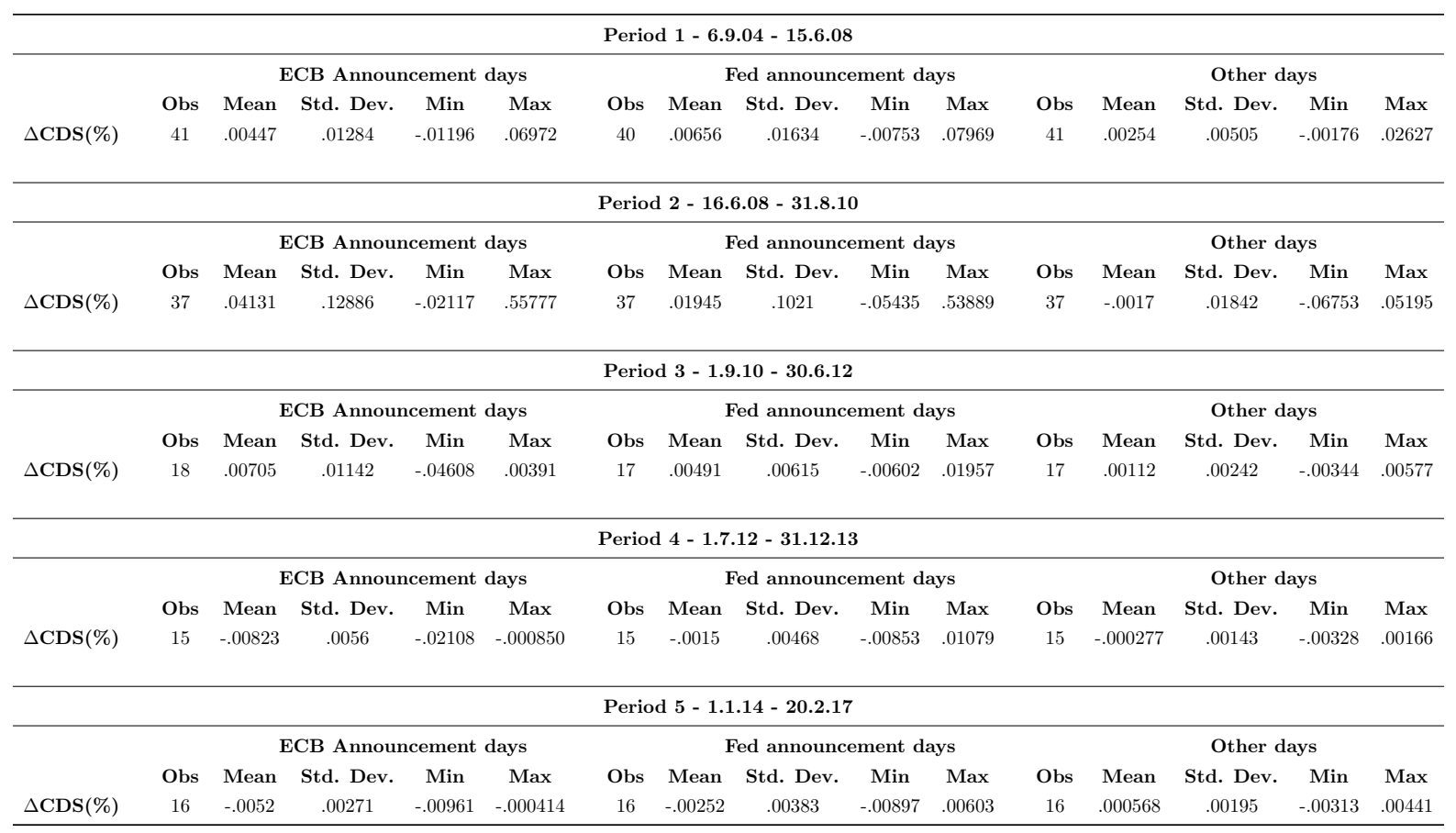

Regressors, besides the previously mentioned change in the risk-free rates for Euro $\left(\triangle R F R_{t=t_{a E C B}}^{E C B}\right)$ and USD ( $\triangle R F R_{t=t_{a F E D}}^{F E D}$ ), also include the VIX, the CESI EUR and the CESI USD indices as control variables. Table 6 displays summary statistics of the independent variables for the five periods of observation. 
Table 6: Descriptive Statistics (Monetary Policy Surprise).

The table reports summary statistics of: $i$ ) the control variables CEIS EUR, CEIS US and VIX; ii) the first principal component of changes in 1-year, 3-year, 5-year, 7-year, and 10-year zero-coupon interest rates for the US and the EU. Statistics are reported for ECB announcement days, FED announcement days, and other days in the observation window.

\begin{tabular}{|c|c|c|c|c|c|c|c|c|c|c|c|c|c|c|c|}
\hline \multicolumn{16}{|c|}{ Period 1 - 6.9.04 - 15.6.08 } \\
\hline & \multicolumn{5}{|c|}{ ECB Announcement days } & \multicolumn{5}{|c|}{ Fed announcement days } & \multicolumn{5}{|c|}{ Other days } \\
\hline Variable & Obs & Mean & Std. Dev. & Min & Max & Obs & Mean & Std. Dev. & Min & Max & Obs & Mean & Std. Dev. & Min & Max \\
\hline$\Delta R F R_{t=t_{a E C B}}^{E C B}$ & 49 & -0.134 & 9.003 & -16.573 & 32.186 & 42 & -0.776 & 6.989 & -20.416 & 19.449 & 562 & 0.194 & 6.788 & -18.351 & 25.996 \\
\hline CESIUSDIndex & 49 & -1.339 & 43.912 & -98.500 & 72.900 & 42 & -0.498 & 42.068 & -102.500 & 76.900 & 562 & -4.455 & 39.125 & -107.600 & 66.400 \\
\hline CESIEURIndex & 49 & 23.308 & 61.417 & -105.200 & 146.500 & 42 & 24.524 & 55.484 & -100.400 & 147.300 & 562 & 25.729 & 59.310 & -114.300 & 162.5 \\
\hline
\end{tabular}

\begin{tabular}{|c|c|c|c|c|c|c|c|c|c|c|c|c|c|c|c|}
\hline \multicolumn{16}{|c|}{ Period 2 - 16.6.08 - 31.8.10 } \\
\hline & \multicolumn{5}{|c|}{ ECB Announcement days } & \multicolumn{5}{|c|}{ Fed announcement days } & \multicolumn{5}{|c|}{ Other days } \\
\hline Variable & Obs & Mean & Std. Dev. & Min & Max & Obs & Mean & Std. Dev. & Min & Max & Obs & Mean & Std. Dev. & Min & $\operatorname{Max}$ \\
\hline$\Delta R F R_{t=t_{a E C}}^{E C B}$ & 27 & -0.517 & 11.443 & -21.619 & 24.329 & 32 & -3.186 & 8.932 & -24.745 & 11.753 & 302 & 0.463 & 8.953 & -39.673 & 30.702 \\
\hline CESIUSDIndex & 27 & -0.033 & 45.946 & -120.300 & 73.600 & 32 & -9.316 & 52.044 & -136.100 & 59.800 & 302 & 5.370 & 48.074 & -140.600 & 72.500 \\
\hline CESIEURIndex & 27 & -14.581 & 91.203 & -188.600 & 121.200 & 32 & -37.559 & 86.161 & -186.500 & 110.300 & 302 & -10.443 & 86.349 & -185.300 & 131.0 \\
\hline VIXIndex & 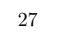 & 315 & 13.808 & 480 & .680 & 32 & .510 & 137 & 7.690 & 9.960 & 02 & .606 & 12.641 & 15.590 & 80.86 \\
\hline
\end{tabular}

\begin{tabular}{|c|c|c|c|c|c|c|c|c|c|c|c|c|c|c|c|}
\hline \multicolumn{16}{|c|}{ Period 3 - 1.9.10 - 30.6.12 } \\
\hline & \multicolumn{5}{|c|}{ ECB Announcement days } & \multicolumn{5}{|c|}{ Fed announcement days } & \multicolumn{5}{|c|}{ Other days } \\
\hline Variable & Obs & Mean & Std. Dev. & Min & Max & Obs & Mean & Std. Dev. & Min & Max & Obs & Mean & Std. Dev. & Min & Max \\
\hline$\Delta R F R_{t=t_{a E C B}}^{E C B}$ & 24 & 0.055 & 11.918 & -19.863 & 34.756 & 22 & -0.015 & 8.222 & -18.761 & 14.484 & 267 & 0.835 & 8.956 & -33.874 & 35.864 \\
\hline$\Delta R F R_{t=t_{a F E D}}^{F E D}$ & 24 & 0.866 & 13.071 & -35.070 & 22.639 & 22 & -0.359 & 12.512 & -23.012 & 38.000 & 267 & 0.369 & 11.085 & -30.759 & 42.212 \\
\hline CESIUSDIndex & 24 & 8.196 & 54.739 & -98.200 & 86.100 & 22 & -1.523 & 58.295 & -98.500 & 77.300 & 267 & 2.449 & 51.334 & -117.200 & 91.900 \\
\hline CESIEURIndex & 24 & 7.658 & 50.335 & -91.700 & 114.900 & 22 & 2.927 & 49.961 & -104.200 & 83.300 & 267 & 2.227 & 48.326 & -103.300 & 104.000 \\
\hline VIXIndex & 24 & 21.638 & 6.163 & 15.950 & 36.270 & 22 & 22.810 & 7.123 & 14.800 & 37.320 & 267 & 21.881 & 6.441 & 14.260 & 45.450 \\
\hline \multicolumn{16}{|c|}{ Period $4-1.7 .12-31.12 .13$} \\
\hline & \multicolumn{5}{|c|}{ ECB Announcement days } & \multicolumn{5}{|c|}{ Fed announcement days } & \multicolumn{5}{|c|}{ Other days } \\
\hline Variable & Obs & Mean & Std. Dev. & Min & Max & Obs & Mean & Std. Dev. & Min & Max & Obs & Mean & Std. Dev. & Min & Max \\
\hline$\Delta R F R_{t=t_{a E C B}}^{E C B}$ & 20 & -0.137 & 9.071 & -13.963 & 18.630 & 17 & -0.881 & 6.631 & -16.564 & 9.683 & 213 & 0.231 & 6.001 & -15.131 & 27.528 \\
\hline$\Delta R F R_{t=t_{a F E D}}^{F E D}$ & 20 & 1.727 & 8.839 & -10.742 & 21.538 & 17 & 0.334 & 15.014 & -31.617 & 36.271 & 213 & -0.369 & 6.399 & -16.664 & 21.173 \\
\hline CESIUSDIndex & 20 & 5.915 & 34.360 & -60.200 & 59.600 & 17 & 5.106 & 32.667 & -62.300 & 48.500 & 213 & 14.898 & 28.639 & -64.900 & 60.700 \\
\hline CESIEURIndex & 20 & -7.455 & 46.096 & -79.000 & 71.900 & 17 & 0.800 & 46.350 & -77.900 & 69.100 & 213 & -4.162 & 40.456 & -83.000 & 69.200 \\
\hline VIXIndex & 20 & 15.303 & 1.761 & 12.940 & 18.490 & 17 & 15.208 & 1.917 & 12.670 & 18.960 & 213 & 14.811 & 2.014 & 11.300 & 22.720 \\
\hline \multicolumn{16}{|c|}{ Period $5-1.1 .14-20.2 .17$} \\
\hline & \multicolumn{5}{|c|}{ ECB Announcement days } & \multicolumn{5}{|c|}{ Fed announcement days } & \multicolumn{5}{|c|}{ Other days } \\
\hline Variable & Obs & Mean & Std. Dev. & Min & Max & Obs & Mean & Std. Dev. & Min & Max & Obs & Mean & Std. Dev. & Min & Max \\
\hline$\Delta R F R_{t=t_{a E C B}}^{E C B}$ & 33 & 1.161 & 8.703 & -20.767 & 26.883 & 29 & -0.246 & 4.670 & -9.935 & 14.603 & 511 & -0.005 & 4.578 & -22.545 & 20.976 \\
\hline$\triangle R F R_{t=t_{a F E D}}^{F E D}$ & 33 & 2.728 & 6.768 & -8.899 & 16.123 & 29 & -2.894 & 14.906 & -35.043 & 26.710 & 511 & -0.164 & 9.168 & -41.082 & 35.474 \\
\hline CESIUSDIndex & 33 & -8.336 & 30.214 & -55.000 & 63.900 & 29 & -10.083 & 29.814 & -71.900 & 50.700 & 511 & -8.408 & 28.973 & -73.300 & 72.700 \\
\hline CESIEURIndex & 33 & 2.018 & 31.979 & -55.000 & 66.100 & 29 & -1.286 & 28.871 & -50.600 & 57.600 & 511 & 5.014 & 31.385 & -71.100 & 75.600 \\
\hline VIXIndex & 33 & 14.713 & 3.447 & 10.320 & 26.690 & 29 & 15.019 & 3.224 & 10.610 & 23.110 & 511 & 15.641 & 4.152 & 10.580 & 40.740 \\
\hline
\end{tabular}

ECB announcement days had different impacts on the interest rates during different periods of observation. Periods 1, 2, and 4 displayed an average decrease in the rates on announcement days, with average interest rate changes of $-0.134 \%,-0.517 \%$ and $-0.137 \%$, respectively, and with significant variations from the changes on "Other days", which were reported to be $+0.194 \%$ in period $1,+0.463 \%$ in period 2 , and $+0.231 \%$ in period 4 . Periods 3 and 5 exhibited the opposite reaction in rates, with, on average, a positive change in interest rates $(+0.055 \%$ and $+1.161 \%$ ), and with variations from the changes on "Other days" of $+0.835 \%$ in period 3 and $-0.005 \%$ in period 5 . The change in interest rates in response to monetary policy actions can be explained by the fact that the intervention either was in the direction of a decrease in interest rates or, despite being for a reduction of interest rates, did not match the expectation of the market that reacted in the opposite direction. 


\subsection{Analysis of the determinants}

For the analysis of determinants, we retrieved from SNL Financials the year-end balance sheet data of the panel of 70 European (re)insurers used in the monetary policy impact analysis. From a time perspective, because SNL Financials possessed sufficiently complete figures from 2003, we based our analysis on a set of 14 year-end balance sheets, from 2003 to 2016. Summary statistics on the utilized balance sheet indicators are provided in Table 7 .

Table 7: Balance Sheet Indices.

This table reports the summary statistics for the items utilized in the analysis of determinants. The indices are built on the balance sheet items reported by the (re)insurers from 2003 to 2016. Source: SNL Financials.

\begin{tabular}{lrrrrr}
\hline \multicolumn{1}{c}{ Indicator } & Obs. & Mean & Std. Dev. & Min & Max \\
\hline Total Assets (Ln) & 520 & 2.784 & 0.178 & 2.217 & 3.033 \\
Fixed Income Assets & 486 & 0.620 & 0.281 & 0.000 & 1.000 \\
Equity Assets & 490 & 0.114 & 0.129 & 0.000 & 0.806 \\
Cash \& Equivalent & 510 & 0.189 & 0.119 & 0.003 & 0.338 \\
Non-Insurance Activities & 472 & 0.375 & 0.223 & 0.082 & 0.998 \\
Life Business & 450 & 0.712 & 0.876 & 0.000 & 5.849 \\
Unit-Linked Business & 466 & 0.384 & 0.412 & 0.000 & 0.376 \\
Dividend Payout & 492 & -0.379 & 1.913 & -11.621 & 18.868 \\
\hline
\end{tabular}

\section{Empirical evidences}

In this section we report the application of the approach explained in Section 2. We start with the analysis of the monetary policy impact, and first show the results of the event study centered on the ECB announcement of the last QE (22/01/2015) on the defined samples of (re)insurers. Subsequently, with the aim of scrutinizing the general effect of a series of several interrelated monetary policy interventions, we display the outcome of the analysis on the monetary policy surprise effect, by enlarging the timeframe of our analysis and the number of interventions announced by the Central Banks. In the second part we move to the analysis of the determinants. In an attempt to identify the characteristics that render (re)insurers more prone to monetary policy interventions, we present empirical evidence obtained via OLS regressions (ref. equation 8).

\subsection{Monetary Policy Impact Analysis}

\subsubsection{Event study}

We designed the event study based on an event window of $-2 /+2$ days (see shaded cells in Table 8). We select a 4-day event window in order to capture the expectation effect that would be reflected in prices in the few days before the announcement on the one hand, and the adjustments subsequent the announcement on the other hand. A longer event window would be prone to capture spurious effects originating from other events that may happen in the market. 
According to this specification, the QE has a significant negative impact on the return of the full sample of (re)insurers (column Total). The same can be observed regarding the different geographical and size-based subsamples. In this respect, however, the level of significance is insufficient. The only exception is represented by the US subsample (column US). This subsample reports impacts that are small but of higher significance compared to those in the full sample. This result cannot be explained based on the information available. It also cannot be connected to the ECB intervention. Therefore, it may be related to other concurrent events and hence deserves further analysis. The evolution of CARs over time for country-based subsamples is provided in Appendix A.1.

Table 8: Event Study.

The table reports the mean of the cumulative abnormal returns of the (re)insurers in different samples, for different combinations of event and estimation window lengths. Significance of the parameter expressed via T-statistics $*=10 \%$ level, $* *=5 \%$ level, $* * * 2.5 \%$ level.

\begin{tabular}{|c|c|c|c|c|c|c|c|c|c|c|c|}
\hline \multicolumn{2}{|c|}{ Parameters } & \multicolumn{10}{|c|}{ Cumulative Abnormal Return } \\
\hline \multirow[b]{2}{*}{$\begin{array}{l}\text { event window } \\
\text { (days) }\end{array}$} & \multirow[b]{2}{*}{$\begin{array}{l}\text { estimation window } \\
\text { (days) }\end{array}$} & \multicolumn{2}{|c|}{ Total } & \multicolumn{2}{|c|}{ mean(small-big) } & \multicolumn{2}{|c|}{ EU } & \multicolumn{2}{|c|}{ EMU } & \multicolumn{2}{|c|}{ US } \\
\hline & & $\begin{array}{l}\text { value } \\
(\%)\end{array}$ & sig. & $\begin{array}{c}\text { value } \\
(\%)\end{array}$ & sig. & $\begin{array}{c}\text { value } \\
(\%)\end{array}$ & sig. & $\begin{array}{l}\text { value } \\
(\%)\end{array}$ & sig. & $\begin{array}{l}\text { value } \\
(\%)\end{array}$ & sig. \\
\hline$-2 /+2$ & 100 & -1.376 & $*$ & -0.588 & - & 0.124 & - & 0.028 & - & -2.456 & $*$ \\
\hline$-2 /+2$ & 250 & -0.854 & $*$ & 0.220 & - & 0.140 & - & -0.075 & - & -1.530 & $* *$ \\
\hline$-2 /+2$ & 350 & -0.836 & $* *$ & 0.386 & - & -0.011 & - & -0.223 & - & -1.397 & $* * *$ \\
\hline$-1 /+1$ & 100 & -0.017 & - & 0.752 & - & -0.031 & - & -0.603 & $*$ & -0.053 & - \\
\hline$-1 /+1$ & 250 & 0.338 & - & 1.291 & - & -0.016 & - & -0.683 & $*$ & 0.536 & - \\
\hline$-1 /+1$ & 350 & 0.337 & - & 1.394 & - & -0.140 & - & -0.770 & $*$ & 0.622 & - \\
\hline $0 / 0$ & 100 & 0.460 & $*$ & -0.299 & - & 0.245 & - & 0.420 & - & 0.494 & - \\
\hline $0 / 0$ & 250 & 0.573 & $*$ & -0.040 & - & 0.272 & - & 0.324 & - & 0.656 & $*$ \\
\hline $0 / 0$ & 350 & 0.551 & $* * *$ & -0.017 & - & 0.213 & - & 0.290 & - & 0.656 & $*$ \\
\hline $0 /+1$ & 100 & 0.148 & - & 0.791 & - & -0.014 & - & -0.521 & - & 0.098 & - \\
\hline $0 /+1$ & 250 & 0.382 & - & 1.151 & - & -0.020 & - & -0.639 & - & 0.495 & - \\
\hline $0 /+1$ & 350 & 0.376 & - & 1.208 & $*$ & -0.110 & - & -0.701 & - & 0.544 & - \\
\hline $0 /+2$ & 100 & -0.133 & - & 0.404 & - & 0.048 & - & -0.240 & - & -0.487 & - \\
\hline $0 /+2$ & 250 & 0.199 & - & 0.930 & - & 0.011 & - & -0.404 & - & 0.117 & - \\
\hline $0 /+2$ & 350 & 0.197 & - & 1.012 & $*$ & -0.091 & - & -0.495 & - & 0.179 & - \\
\hline $0 /+3$ & 100 & -0.025 & - & 0.146 & - & -0.001 & - & -0.278 & - & -0.336 & - \\
\hline $0 /+3$ & 250 & 0.457 & - & 0.797 & - & -0.001 & - & -0.380 & - & 0.515 & - \\
\hline $0 /+3$ & 350 & 0.496 & $*$ & 0.911 & - & -0.120 & - & -0.487 & - & 0.665 & $*$ \\
\hline
\end{tabular}

As a robustness check, we tested other event windows without obtaining statistically significant results. Furthermore, the direction and significance of the impacts of the QE announcement are strongly dependent on the parameters of the event study, namely the size of the event window and the estimation window (see Table 8 above in the non-shaded cells). In fact, when restricting the event window to the day of the announcement $(-0 /+0)$, the empirical evidence offers the same picture, albeit with the opposing sign and lower magnitude. The smaller coefficients, despite their significance, reveal how the market reflected the expected monetary action 
in the preceding days, leaving some adjustments for the day of the announcement. From the event study, we were unable to reach a clear-cut conclusion regarding the impact of the last ECB QE announcement on (re)insurers. The limited and somewhat contradictory evidence suggests that the $2015 \mathrm{QE}$ was not well received by the insurance market. However, the limited magnitude and volatility of the direction of the impact suggest the need for a wider approach that evaluates general monetary policy strategy encompassing several interventions enforced by the Central Banks.

\subsubsection{Monetary policy surprise}

Monetary policy interventions cannot be considered standalone actions; they are at simultaneously both the cause and the consequence of complex and interrelated macroeconomic circumstances. The analysis of a standalone event (e.g. a QE announcement) excerpted from the larger set of monetary policy actions encompassed in the overall monetary policy strategy may lead to partial and potentially misleading results. In order to overcome this, we propose an identification approach that takes direct inspiration from Rogers et al. (2014) and Pericoli and Veronese (2016). According to the authors, monetary policy interventions are transmitted to the market through variation in yields over the whole interest rate term structure. The effects of Central Bank announcements are signaled by statistically significant higher monetary policy surprise during event days compared to non-event days. This can be observed in each of the five periods (Table 9 Monetary Policy Surprise - Volatility of the first component of the interest rate term structure). Furthermore, market returns of (re)insurers and other listed institutions reflect announcement events, but with a statistically significant increase in volatility limited to the first three periods. 
Table 9: Monetary Policy Surprise - Volatility of the first component of the interest rate term structure.

The table reports the volatility of $i$ ) the first PCA factor using the 1-year, 3-year, 5-year, 7-year and 10-year bond yield dissected for the Euro area and the US and for the different periods of observation; ii) the market returns of the (re)insurers included in the sample, and iii) the market returns of the indices of financial services deducted by (re)insurers.

Additionally, the $P$-value for the one sided $F$-test of difference in variances is reported, namely

$$
H_{0}: \sigma_{\text {event }}>\sigma_{\text {no-event }} \text {. }
$$

\begin{tabular}{|c|c|c|c|c|c|c|}
\hline \multicolumn{7}{|c|}{ Monetary Policy Surprise } \\
\hline & & ECB & & & Fed & \\
\hline Period & $\sigma_{\text {event }}$ & $\sigma_{n o-e v e n t}$ & $p$-val & sev & snev & $p$-val \\
\hline 1 & 27.854 & 23.081 & 0.000 & 26.188 & 23.082 & 0.000 \\
\hline 2 & 40.807 & 32.247 & 0.000 & 46.669 & 29.809 & 0.000 \\
\hline 3 & 30.816 & 25.348 & 0.000 & 17.845 & 14.916 & 0.000 \\
\hline 4 & 20.308 & 15.223 & 0.000 & 23.016 & 14.807 & 0.000 \\
\hline 5 & 22.430 & 18.007 & 0.000 & 21.077 & 14.350 & 0.000 \\
\hline \multicolumn{7}{|c|}{ (re)insurers' returns } \\
\hline & & ECB & & & Fed & \\
\hline Period & $\sigma_{\text {event }}$ & $\sigma_{n o-e v e n t}$ & $p$-val & sev & snev & $p$-val \\
\hline 1 & 0.239 & 0.118 & 0.000 & 0.234 & 1.988 & 0.118 \\
\hline 2 & 0.376 & 0.181 & 0.084 & 0.406 & 3.511 & 0.181 \\
\hline 3 & 0.376 & 0.174 & 0.000 & 0.373 & 2.131 & 0.174 \\
\hline 4 & 0.285 & 0.440 & 0.685 & 0.464 & 1.487 & 0.440 \\
\hline 5 & 0.281 & 0.862 & 0.685 & 0.467 & 1.487 & 0.862 \\
\hline \multicolumn{7}{|c|}{ Other returns } \\
\hline & & ECB & & & Fed & \\
\hline Period & $\sigma_{\text {event }}$ & $\sigma_{n o-e v e n t}$ & $p$-val & sev & snev & $p$-val \\
\hline 1 & 0.481 & 0.337 & 0.000 & 0.251 & 0.347 & 0.125 \\
\hline 2 & 0.859 & 0.771 & 0.094 & 0.958 & 0.764 & 0.174 \\
\hline 3 & 0.584 & 0.455 & 0.001 & 0.344 & 0.467 & 0.162 \\
\hline 4 & 0.383 & 0.300 & 0.633 & 0.618 & 0.390 & 0.370 \\
\hline 5 & 0.420 & 0.623 & 0.546 & 0.618 & 0.390 & 0.562 \\
\hline
\end{tabular}

According to our results, monetary policy interventions have a statistically significant impact on the stock returns during the first three periods of analysis. In particular, interventions that generate an instantaneous reduction in interest rates tested via equation 5 appear to be negatively received by the markets (ref. periods 1 and 2), whereas a series of interventions generating an increase in interest rates appears to have a positive effect (period 3). From a financial stability perspective, periods 2 and 3 are the more interesting, as they cover the two most recent crises: the sub-prime crisis (period 2) and the European sovereign debt crisis (period 3). During those periods, both the ECB and FED interventions pointed in the same 
direction, with the impact of the ECB interventions being more effective over the five periods of observation. As a matter of fact, the coefficients associated with the monetary ECB and FED interventions are always positive when statistically significant (ref. Figure 2). Those positive coefficients transfer the movements of the interest rates triggered by the monetary policy interventions (positive/negative sign of the PCA of risk-free rate term structures for different maturities) to movements in the stock returns of the targeted companies without any change in the direction. ${ }^{7}$

This is also in line with the comparison of stock returns observed during monetary policy days and "other days". As displayed in Table 4 during the first two periods, when monetary policy impacts are deemed to have negative impacts on the market, the stock returns observed during monetary policy days are lower than those observed on "other days", and period 3 shows the opposite behavior.

Furthermore, it worth noting that even if a statistically significant impact can also be observed in the first period of observation, the values of the coefficient associated with the monetary policy surprise are smaller than during crisis periods, signaling a lower effectiveness of Central Bank interventions during "tranquil" periods.

Figure 2 also shows that the effect of expansionary monetary policy intervention on stock returns tends to fade away in the fourth and fifth periods. We find two potential explanations for this behavior. The first is the low level reached by interest rates during those two periods (ref. Figure 1). Indeed, for 1 year starting from September 2012, the shortest maturities (1 and 2 years) fluctuated around the zero level and the mid-term maturities (5 year) were below $1 \%$. During the $5^{t h}$ period, the economy entered into the so-called low-yield environment with all maturities below or close to zero. The second rationale lies in the definition of the stock prices: markets were at this stage somehow "addicted" to prolonged and unidirectional monetary policy interventions that, according to the statements of Central Banks, were expected to last for long; therefore, stock prices might have already included all further conventional and unconventional expansionary monetary policy actions.

The dissection between (re)insurers and other companies shows a slightly lower impact of the monetary policy surprises in the insurance industry. This difference can be traced back to the insurance balance sheet structure. The effect of a reduction of interest rates on the balance sheet of an insurer is in fact twofold: if, on the one hand, the increase in the price of fixed income assets have a positive effect on the capital position, on the other hand, the reduction in yields increases the present value of the technical provisions and renders (re)insures potentially prone to mismatches in future positive and negative cash flows.

\footnotetext{
${ }^{7}$ For a tabular representation of the interactions among monetary policy surprise (first principal component of the interest rates term structure), the sign of the coefficients associated to them via OLS regression (ref. 5), and the net impact on stock prices, refer to Appendix A.4.
} 
Figure 2: ECB and FED coefficient over time Full sample. This figure graphically represents the coefficient of the monetary policy surprise explanatory variables as described in equation (5) and reported in Appendix A). Transparent bars represent non-significant coefficients (T-statistics $>10 \%$ level).

(a) ECB

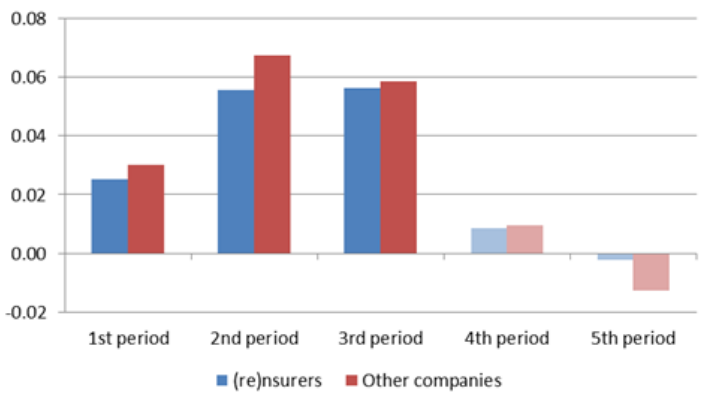

(b) FED

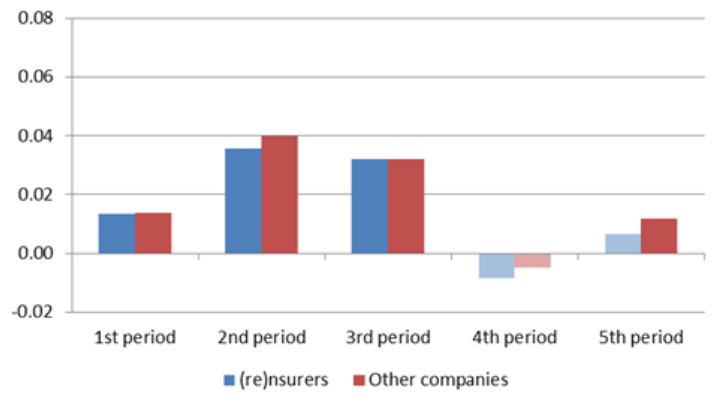

These results were confirmed when we analyzed geographical subsamples based on macroareas, but with some distinctions (ref. Figure 3). In addition to the confirmation of the significance observed in the first three periods, the results show how, during crisis periods, the impact of ECB monetary policies on EMU institutions is higher than that on other geographical subsamples. The relatively small difference in coefficients can be explained by the cross-border nature of the business run by the institutions included in the analysis. Indeed, we are investigating the impact of monetary interventions on the listed groups operating globally. Therefore, although to some extent geographical criteria were observed (EMU and US subsamples for ECB and Fed interventions, respectively), any action on a specific currency only partially affects the returns and the capital positions of those institutions. Interestingly, the sign of the coefficients observed in the fifth period, even if not statistically significant, turn to negative, confirming the negative impact both on (re)insurers and on other companies in the sample. In an ultra-low interest rate environment, even if monetary interventions by ECB lead to an increase in interest rates as observed on announcement days, the movements are negatively reflected by the market. This finding is in line with results obtained from the event study. The actions taken by the FED and ECB tend to point in the same direction, but with some specificity. According to our results, the impact of the FED monetary policy actions on both (re)insurers and non-insurers is usually larger, but appear to be limited to the US market (ref. Appendix A.3).

Those considerations can be extended, with some distinctions, to both (re)insurers and other listed companies operating in different geographical areas, as shown in Figure 3. 
Figure 3: ECB coefficient over time Subsamples

This figure graphically represents the coefficient of the monetary policy surprise explanatory variables as described in equation (5) and reported in Appendix A). Transparent bars represent non-significant coefficients (T-statistics $>10 \%$ level).

(a) (re)insurers

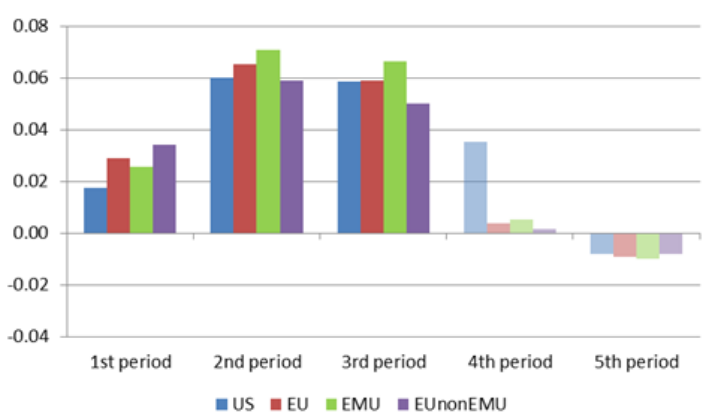

(b) other listed companies

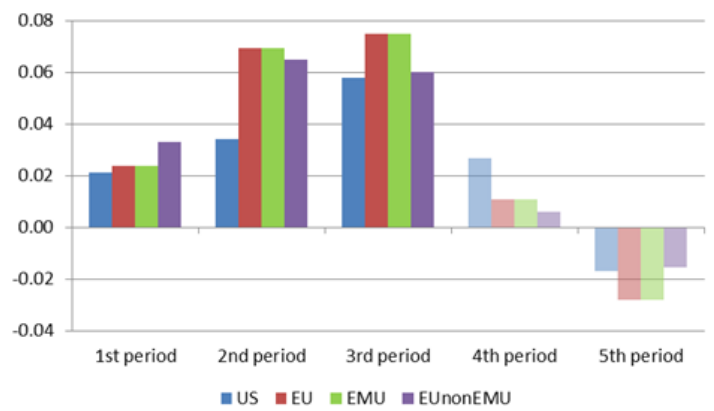

The local perspective at the EU level confirms the general outcomes (Figure 4), with statistically significant results in the first three periods and larger impacts concentrated in periods 2 and 3. ECB monetary policy actions have heterogeneous effects across EU jurisdictions, with larger impacts observed in Belgium, France, Netherlands, and Spain, followed by Italy. The traditionally large exposures to long-term with-profit life contracts backed by fixed income assets of insurers based in these countries could serve as an explanation for the high sensitivity to changes in interest rates.

In concordance with doubts about Greece's Euro-reversibility from the European Sovereign debt crisis onward, and the exclusion of Greece from the ECB QE programme, this jurisdiction appears to be only marginally affected by the monetary policy actions enforced by the ECB. Coefficients are indeed not statistically significant throughout the periods of observation.

The comparison between industries shows how, in highly affected jurisdictions, the impact of monetary policy actions is larger in the insurance industry, whereas in other countries such as Austria, Denmark, and Norway, the reaction is larger in the non-insurance industry. Again, the asset and liability composition of the (re)insurers based in these jurisdictions could provide an explanation of this result. 
Figure 4: ECB intervention monetary policy surprise: country-based impact on (re)insurers This figure graphically represents the coefficient of the monetary policy surprise explanatory variables as described in equation (5) and reported in Appendix A). Transparent bars represent non-significant coefficients (T-statistics $>10 \%$ level).

(a) core Euro area

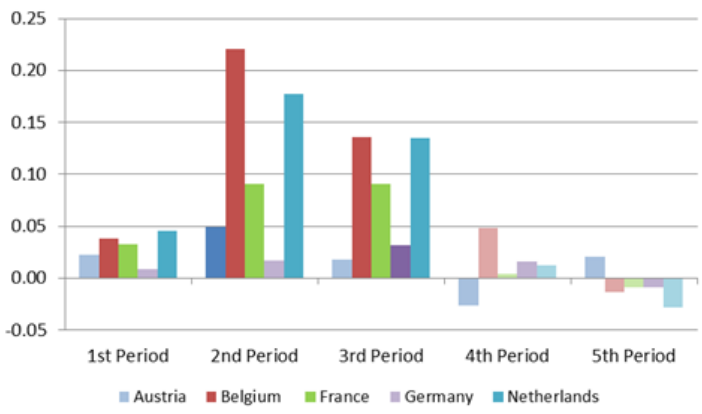

(b) peripheral Euro area

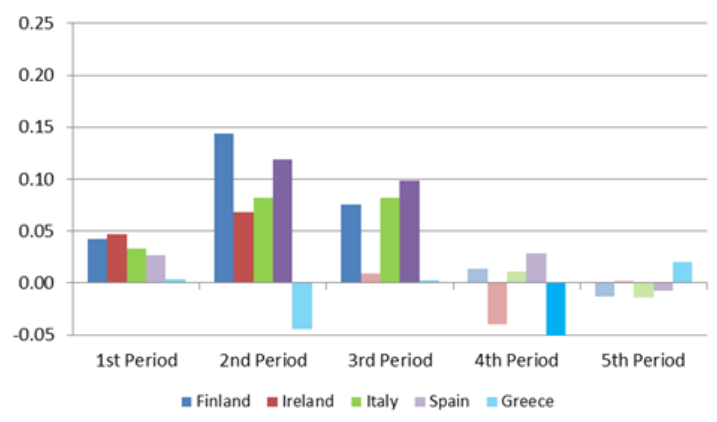

The figures displayed so far stem from equation 5 , calculated with a 3-day window (2 days prior and the announcement day). In order to test potential behaviors of the companies, we ran the regression after moving the 3-day window around the announcement day. The different windows show a moderate trend among (re)insurers to anticipate announcements rather than reacting to them with some delay. Indeed, as shown in the appendix A.5 the coefficients and level of significance decrease when moving from the specification -2 days, announcement day to announcement day, +2 days

Summarizing, expansionary monetary policy actions that lead to an immediate decrease in interest rate had negative effects on the stock returns of the companies included in our sample. On the contrary, when the interest rates increased, we observed positive reactions in the markets. Monetary policy actions produce larger effects on markets during crises periods. Additionally, the effectiveness of conventional and unconventional monetary policy actions appears to fade away after a prolonged period of enforcement and in ultra-low-yield environments. The asset and liability structure of (re)insurers appears to dampen the impact of changes in interest rates, compared to other sectors of the economy.

\subsubsection{Reactions of the CDS market}

The impact on the CDS market confirms the detrimental effect of monetary policy interventions that cause an immediate reduction in the risk-free rate curve, on (re)insurance undertakings (see Table 10). 
Table 10: CDS reactions.

The table reports the outcome of the impacts of monetary policy surprise on CDS spreads of (re)insurers according to equation 6 (dependent variable is scaled by 100).

Robust t-statistics in parentheses. ${ }^{* * *} p<0.01,{ }^{* *} p<0.05,{ }^{*} p<0.1$.

\begin{tabular}{|c|c|c|c|c|c|}
\hline VARIABLES & 1st Period & 2nd Period & 3rd Period & 4th Period & 5th Period \\
\hline$\Delta R F R_{t=t_{a E C B}}^{E C B}$ & $\begin{array}{c}-0.001 * * * \\
(-3.01)\end{array}$ & $\begin{array}{c}-0.003^{* * *} \\
(-2.74)\end{array}$ & $\begin{array}{c}-0.002^{* * *} \\
(-3.13)\end{array}$ & $\begin{array}{l}-0.000 \\
(-0.07)\end{array}$ & $\begin{array}{l}0.000 \\
(0.18)\end{array}$ \\
\hline VIXIndex & $\begin{array}{c}0.001 * * * \\
(3.13)\end{array}$ & $\begin{array}{c}0.005^{* * *} \\
(3.98)\end{array}$ & $\begin{array}{l}0.000 \\
(0.11)\end{array}$ & $\begin{array}{c}0.002^{* *} \\
(2.01)\end{array}$ & $\begin{array}{l}0.001 \\
(1.24)\end{array}$ \\
\hline CESIEURIndex & $\begin{array}{l}0.000 \\
(1.64)\end{array}$ & $\begin{array}{l}0.000^{*} \\
(1.65)\end{array}$ & $\begin{array}{l}-0.000 \\
(-0.86)\end{array}$ & $\begin{array}{l}0.000 \\
(0.65)\end{array}$ & $\begin{array}{l}-0.000 \\
(-0.30)\end{array}$ \\
\hline Constant & $\begin{array}{c}-0.016^{* * *} \\
(-3.36)\end{array}$ & $\begin{array}{c}-0.128^{* * *} \\
(-3.82)\end{array}$ & $\begin{array}{l}-0.005 \\
(-0.28)\end{array}$ & $\begin{array}{c}-0.045^{* *} \\
(-2.29)\end{array}$ & $\begin{array}{l}-0.020 \\
(-1.53)\end{array}$ \\
\hline $\begin{array}{l}\text { Observations } \\
\text { R-squared }\end{array}$ & $\begin{array}{c}412 \\
0.091\end{array}$ & $\begin{array}{c}238 \\
0.106\end{array}$ & $\begin{array}{c}147 \\
0.135\end{array}$ & $\begin{array}{c}117 \\
0.027\end{array}$ & $\begin{array}{c}64 \\
0.021\end{array}$ \\
\hline \multicolumn{6}{|c|}{ FED announcement days } \\
\hline VARIABLES & 1st Period & 2nd Period & 3rd Period & 4th Period & 5th Period \\
\hline$\Delta R F R_{t=t_{a F e d}}^{F e d}$ & $\begin{array}{l}-0.000 \\
(-1.25)\end{array}$ & $\begin{array}{l}-0.001 \\
(-1.59)\end{array}$ & $\begin{array}{l}-0.000 \\
(-1.56)\end{array}$ & $\begin{array}{l}-0.000 \\
(-1.02)\end{array}$ & $\begin{array}{c}-0.000^{*} \\
(-1.74)\end{array}$ \\
\hline VIXIndex & $\begin{array}{c}0.002^{* * * *} \\
(4.57)\end{array}$ & $\begin{array}{l}-0.000 \\
(-0.45)\end{array}$ & $\begin{array}{l}0.001 \\
(1.03)\end{array}$ & $\begin{array}{l}0.001 \\
(0.40)\end{array}$ & $\begin{array}{l}-0.001 \\
(-0.71)\end{array}$ \\
\hline CESIUSIndex & $\begin{array}{c}0.000 * * * \\
(2.81)\end{array}$ & $\begin{array}{l}0.000 \\
(0.62)\end{array}$ & $\begin{array}{l}0.000 \\
(0.39)\end{array}$ & $\begin{array}{l}0.000 \\
(0.66)\end{array}$ & $\begin{array}{l}0.000 \\
(1.08)\end{array}$ \\
\hline Constant & $\begin{array}{c}-0.026^{* * *} \\
(-4.94)\end{array}$ & $\begin{array}{l}0.020 \\
(0.63)\end{array}$ & $\begin{array}{l}-0.012 \\
(-1.01)\end{array}$ & $\begin{array}{l}-0.013 \\
(-0.58)\end{array}$ & $\begin{array}{l}0.011 \\
(0.64)\end{array}$ \\
\hline Observations & 365 & 281 & 138 & 102 & 60 \\
\hline R-squared & 0.128 & 0.024 & 0.033 & 0.012 & 0.112 \\
\hline
\end{tabular}

Regression 6 based on the first difference in CDS spreads confirms the statistically significant impact of the ECB monetary policy surprise in the first three periods of observation. The significance fades away in periods 4 and 5 , in line with the results obtained for stock returns. Coefficients, when statistically significant, display negative signs; therefore, an immediate reduction of the interest rates triggered by a monetary policy announcement of the ECB generates an increase in the CDS spreads of (re)insurance undertakings. This economic impact is consistent with that observed on stock market returns, namely, a reduction in stock returns is associated with a widening of the CDS spreads. Results related to the Fed monetary policy surprise do not show statistically significant results in any period. This outcome is not aligned with that observed for stock returns. The reduced sample (43 vs. 166) might serve as an explanation for the different behaviors of the regressor in the two specifications.

In the following section, we try to identify the items in the balance sheet of a (re)insurer that determine the higher or lower response to changes in interest rates.

\subsection{Analysis of Determinants}

Table 11 reports the results of the Logit regressions based on indices built on balance sheet items. 
Table 11: Logit regression (balance sheet indices).

The table reports the logit regresison for both asset and liability specifications according to equation 8. Robust standard errors in parentheses. ${ }^{* * *} p<0.01,{ }^{* *} p<0.05,{ }^{*} p<0.1$.

\begin{tabular}{|c|c|c|c|c|c|c|c|c|}
\hline \multirow[b]{2}{*}{ Variables } & \multicolumn{3}{|c|}{ Asset side } & \multicolumn{5}{|c|}{ Liability Side } \\
\hline & (1) & (2) & (3) & (1) & (2) & (3) & $(4)$ & (5) \\
\hline Total Assets (Ln) & $\begin{array}{c}4.381^{* * *} \\
(1.014)\end{array}$ & $\begin{array}{c}4.091^{* * *} \\
(1.177)\end{array}$ & $\begin{array}{c}4.014^{* * *} \\
(1.192)\end{array}$ & & & & & \\
\hline Fixed Income Assets & & $\begin{array}{l}1.206^{*} \\
(0.696)\end{array}$ & $\begin{array}{l}1.184^{*} \\
(0.703)\end{array}$ & & & & & \\
\hline Equity Assets & & $\begin{array}{c}1.805 \\
(1.272)\end{array}$ & $\begin{array}{c}1.911 \\
(1.281)\end{array}$ & & & & & \\
\hline Cash and Equivalent & & & $\begin{array}{l}-0.0327 \\
(0.0827)\end{array}$ & & & & & \\
\hline Life Business & & & & $\begin{array}{c}0.155 \\
(0.151)\end{array}$ & & & $\begin{array}{c}0.122 \\
(0.184)\end{array}$ & $\begin{array}{c}0.261 \\
(0.255)\end{array}$ \\
\hline Non-Insurance Activities & & & & & $\begin{array}{c}0.567 \\
(0.601)\end{array}$ & & $\begin{array}{c}0.233 \\
(0.760)\end{array}$ & $\begin{array}{c}0.322 \\
(0.759)\end{array}$ \\
\hline Unit-Linked Business & & & & & & $\begin{array}{c}0.00103 \\
(0.00325)\end{array}$ & & $\begin{array}{l}-0.00406 \\
(0.00463)\end{array}$ \\
\hline Constant & $\begin{array}{c}-13.15^{* * *} \\
(2.876)\end{array}$ & $\begin{array}{c}-13.36^{* * *} \\
(3.481)\end{array}$ & $\begin{array}{c}-13.13^{* * *} \\
(3.519)\end{array}$ & $\begin{array}{c}-0.806^{* * *} \\
(0.178)\end{array}$ & $\begin{array}{c}-0.979^{* * *} \\
(0.269)\end{array}$ & $\begin{array}{c}-0.772^{* * *} \\
(0.143)\end{array}$ & $\begin{array}{c}-0.871^{* * *} \\
(0.278)\end{array}$ & $\begin{array}{c}-0.993^{* * *} \\
(0.297)\end{array}$ \\
\hline Observations & 260 & 241 & 241 & 225 & 236 & 233 & 225 & 224 \\
\hline
\end{tabular}

Empirical evidence shows how the sensitivity of (re)insurers to monetary policy surprises is driven by the asset side of the balance sheet. In line with our first hypothesis (Hp.1), the exposure of (re)insurers to fixed income assets acts as the main determinant of the sensitivity of (re)insurers to sudden changes in the reference interest rate. The monetary policy announcements indeed have a direct impact on prices of fixed income assets, and only indirect effects on other asset classes, such as equities, which, according to our results, do not play a significant role. An expansionary monetary policy announcement that, as shown in the previous section, leads to a reduction of the risk-free rates across all maturities, causes a contraction in bond yields and a consequent increase in their market prices.

For a (re)insurer, the effect of the reduction in reference interest rates also has an impact on liabilities, with the values of the provisions moving in the opposite direction. This effect is expected to be more pronounced for those businesses that entail a longer duration. Based on this, and according to our second hypothesis (Hp.2), we expected that exposure to the life business would be a determinant of sensitivity to monetary policy surprises. The empirical evidence rejects this hypothesis. Exposures to Life business and to Non-insurance activities traditionally based on maturity transformation are not associated with statistical significance.

Furthermore, we observe that against our expectations (Hp.3), higher or lower engagement in Non-insurance Activities does not play a statistically significant role in determining the sensitivity of (re)insurers to monetary policy surprises. Therefore, our third hypothesis is rejected. In conclusion, our empirical evidence shows how Size acts as a main determinant.

We also tested whether there is a relationship between monetary policy surprises and the 
dividend policies of (re)insurance companies. The results, displayed in Table 12, do not show a statistically significant relationship.

Table 12: Logit regression (balance sheet indices).

The table reports the logit regression for both asset and liability specifications according to equation 8. Robust standard errors in parentheses. ${ }^{* * *} p<0.01,{ }^{* *} p<0.05,{ }^{*} p<0.1$.

\begin{tabular}{lcc}
\hline & \multicolumn{2}{c}{ Dividend distribution } \\
\hline Variables & $(1)$ & $(2)$ \\
& & \\
LogTotAs & & $4.270^{* * *}$ \\
& & $(1.021)$ \\
divpayout & -0.0666 & -0.0404 \\
& $(0.0672)$ & $(0.0926)$ \\
Constant & $-0.853^{* * *}$ & $-12.85^{* * *}$ \\
& $(0.142)$ & $(2.888)$ \\
& & \\
Observations & 246 & 246 \\
\hline
\end{tabular}

\section{Conclusions and way forward}

In this paper, we have investigated the impact of conventional and unconventional monetary policies on the insurance industry by looking at the impact of the actions taken by the ECB on the market returns of (re)insurers. Additionally, we analyzed the characteristics of (re)insurers that drive the sensitivities of the companies to changes in interest rates.

We investigated the impact of monetary policy via two approaches. First, we conducted an event study on the announcement date of the last ECB Quantitative Easing program. We scrutinized the CARs of a sample of 166 (re)insurers split into different subsamples according to size and geographical criteria, and compared this with the behavior of the other market participants. Subsequently, with the aim of understanding the impact of general enforced monetary policy strategy and not of a single event, we enlarged the scope of our analysis by investigating the effects, on the markets in general and on insurers in particular, of a series of announcements made by the ECB and the Fed. To do so, we replicated the approach proposed by Rogers et al. (2014) and Pericoli and Veronese (2016), analyzing how and to what extent the Central Banks announcements are signaled by the markets via changes in the term structure of the risk-free rate.

The event study suggests a moderate negative effect of the QE on the insurance industry. The different specifications we tested show how the outcomes of the event study are strongly dependent on the observation period. Furthermore, we did not obtain statistically significant results for the subsamples. By applying the monetary policy surprise-based model, we document i) how the effect of monetary policy interventions on interest rates in the announcement days changes over time, and ii) the subsequent impact of expansionary monetary policy interventions on the market in general and on the insurance industry in particular. 
Our empirical evidence suggests that when monetary policy actions generate an immediate reduction in interest rates (periods 1 and 2), the effect on stock returns is negative, whereas an increase in interest rates (period 3) is positively received by the markets. The impact on the stock market is larger during crisis periods than in tranquil periods and the effectiveness of the monetary policy actions tend to fade away after prolonged application and in an ultralow-yield environment (periods 4 and 5). This applies both to the ECB and FED actions with one distinction: FED interventions affect larger geographical areas than do ECB ones, with the latter having more concentrated but higher impacts. Monetary policy actions, when producing statistically significant results, have more limited results on (re)insurers than on other companies, particularly with respect to the ECB.

The balance sheet structure of (re)insurers, with assets and liabilities reacting in opposite directions to changes in the interest rates could serve as a rationale for these behaviors. Stock prices are defined by discounted future profits; therefore, the potential negative impacts of reduced interest rates on long-term obligations that characterize the life business overcome the short-term benefits deriving from the mark to market valuation of the assets. This explanation is also in line with the results obtained at the EU country level, where jurisdictions traditionally exposed to long-term obligations are more affected than others.

The impacts on (re)insurers were confirmed by the reactions of the CDS market. Our analysis shows how, during ECB monetary policy days when an instantaneous reduction of the interest rate is observed, the detrimental effect on the stock return is associated with a negative impact on CDS spreads. Given the limited sample, we consider the analysis on CDS still preliminary; however, the results are so far promising and in line with our expectations.

The two applied models returned consistent results. Nevertheless, this work shows how a single intervention extrapolated from the comprehensive strategy should be utilized with caution to estimate the effect of monetary policy intervention on the market.

In the second part of the paper, we investigated the characteristics of (re)insurers based in Europe that drive the reaction to ECB monetary policy actions. To do so, we defined a set of balance sheet-based indicators aimed at capturing the asset allocation and product portfolio composition of each entity. We then used those indices as regressors for the sensitivity of a (re)insurer to monetary policy actions in a logit regression.

According to our results, only size and exposure to fixed income assets seems to drive the sensitivity of (re)insurers to monetary policy interventions. In contrast to our initial hypothesis, none of the liability-based indices provide statistically significant results.

Our balance sheet analysis is limited by the frequency and granularity of the information. This paper would benefit from the availability of complete and accurate quarterly balance sheet data and from a thorough knowledge of the interactions between the assets and liability sides of the insurers, i.e. duration mismatch. Additionally, we do not provide a clear-cut explanation for the documented low effectiveness of the ECB and FED interventions in the last two periods of observation. We propose the prolonged enforcement of unidirectional monetary policy actions and the ultra-low-yield environment as potential explanations; however, at this stage we are unable to be more precise. 
We believe that this work provides an initial valuable contribution to the literature on the analyses of monetary policy, enriching it with a specific focus on the insurance industry. Furthermore, the evidence we provide may be of interest for policymakers, offering them a wider perspective on the impacts that monetary policy actions have on a specific sector. 


\section{A Appendix}

\section{A.1 Event Study}

Figure 5: The impact of the announcement of Quantitative Easing on the insurance sector. The averaged cumulative abnormal return is plotted against time. The red vertical line on 22.01.2015 indicates the announcement of Quantitative Easing by the European Central Bank. It was averaged for firms based in the US and in the European Monetary Union (EMU). The red vertical line on 22.01.2015 indicates the announcement of Quantitative Easing by the European Central Bank.

(a) Full sample

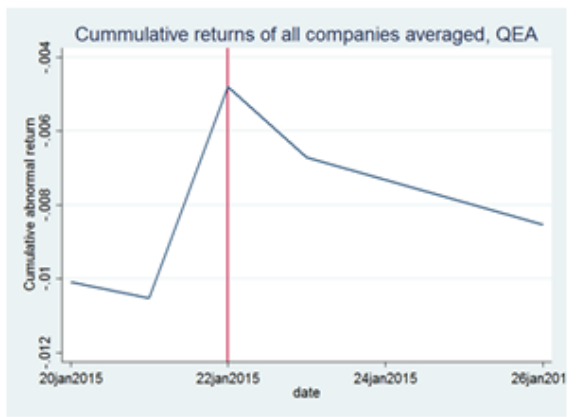

(b) Subsamples

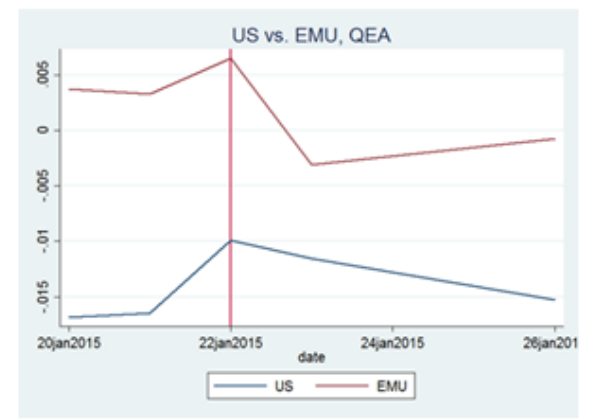

Figure 6: The impact of the announcement of Quantitative Easing on the insurance sector - Country analysis

The cumulative abnormal return (CAR) is plotted against time. The CAR of (re)insurers is averaged for each country. Greece, as excluded from the QE program is reported as a check. The red vertical line on 22.01.2015 indicates the announcement of Quantitative Easing by the ECB.

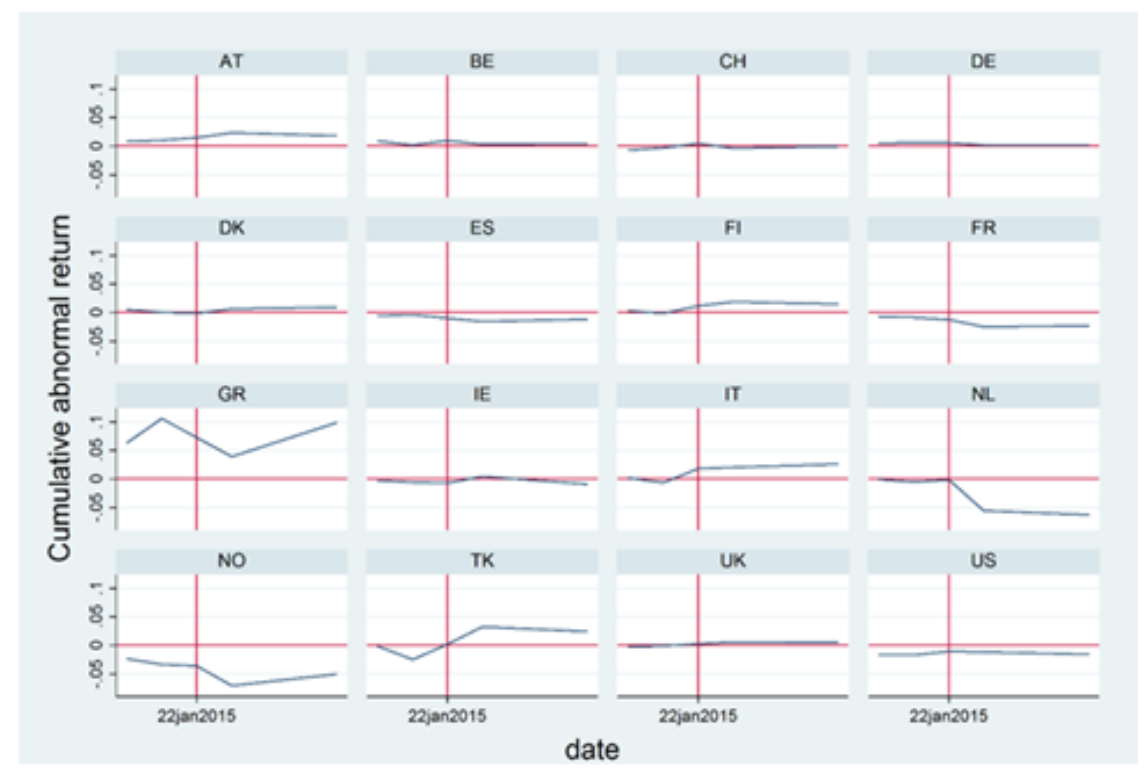




\section{A.2 Monetary policy days}

Table 13: ECB Monetary Policy Days (August 2008 - February 2017).

The table reports a detailed list of regular and extraordinary press releases from the ECB having potential monetary policy implications.

\begin{tabular}{|c|c|c|c|}
\hline \multicolumn{4}{|c|}{ ECB Monetary Policy Days (Detailed - from 08.2008 onwards) } \\
\hline Date & Event & Date & Event \\
\hline 2-Aug-07 & GC meeting & 12-Jan-12 & GC meeting \\
\hline 09-Aug-07 & Special fine tuning operations & 9-Feb-12 & GC meeting, ECB approved criteria for credit claims for $7 \mathrm{NCBs}$ \\
\hline 22-Aug-07 & Supplementary LTRO (amnouncement) & 28-Feb-12 & Results of second 3-year LTRO \\
\hline 23-Aug-07 & Supplementary LTRO (allotment) & 8-Mar-12 & GC meeting \\
\hline 6-Sep-07 & GC meeting & 4-Apr-12 & GC meeting \\
\hline 4-0ct-07 & GC meeting & 3-May-12 & GC meeting \\
\hline 8-Nov-07 & GC meeting & 6-Jun-12 & GC meeting \\
\hline 6-Dec-07 & GC meeting & 5-Jul-12 & GC meeting, MRO rate decreased to $0.75 \%$, deposit facility rate to 0 \\
\hline 10-Jan-08 & GC meeting & 26-Jul-12 & "Whatever it takes" London speech \\
\hline 7-Feb-08 & GC meeting & 2-Aug-12 & GC meeting, OMT \\
\hline 6-Mar-08 & GC meeting & 6-Sep-12 & GC meeting, OMT details \\
\hline 28-Mar-08 & introduce 6-m LTROs & 4-Oct-12 & GC meeting \\
\hline 10-Apr-08 & GC meeting & 8-Nov-12 & GC meeting \\
\hline 8-May-08 & GC meeting & 6-Dec-12 & GC meeting \\
\hline 5-Jum-08 & GC meeting & 10-Jan-13 & GC meeting \\
\hline 3.-Jul-08 & GC meeting, MRO increased to $4.25 \%$ & 7-Feb-13 & GC meeting \\
\hline 7-Aug-08 & GC meeting & 7-Mar-13 & GC meeting \\
\hline 4-Sep-08 & GC meeting & 22-Mar-13 & Collateral rule changes for some uncovered gov-guaranteed bank bonds \\
\hline 8-Oct-08 & GC meeting, MRO decreased to $3.75 \%$, Fixed-rate full allotment (FRFA) on MRO & 4-Apr-13 & GC meeting \\
\hline 6-Nov-08 & GC meeting, MRO decreased to $3.25 \%$ & 2-May-13 & GC meeting, MRO rate decreased to $0.5 \%$, FRFA extended to July 2014 \\
\hline 4-Dec-08 & GC meeting, MRO decreased to $2.50 \%$ & 6-Jun-13 & GC meeting \\
\hline 15-Jan-09 & GC meeting, MRO decreased to $2.00 \%$ & 4-Jul-13 & GC meeting, forward guidance: 'expects the key ECB interest rates to remain at present or lower levels for an extended period of time' \\
\hline 5-Feb-09 & GC meeting & 1-Aug-13 & GC meeting \\
\hline 5-Mar-09 & GC meeting, MRO decreased to $1.50 \%$ & 5-Sep-13 & GC meeting \\
\hline 2-Apr-09 & GC meeting, MRO decreased to $1.25 \%$ & 2-Oct-13 & GC meeting \\
\hline 7-May-09 & GC meeting, MRO decreased to $1.00 \%$, 3year LTROs, CBPP & 7-Nov-13 & GC meeting, MRO rate decreased to $0.25 \%$ \\
\hline 4-Jun-09 & GC meeting, CBPP details announced & 5-Dec-13 & GC meeting \\
\hline 2-Jul-09 & GC meeting & 9-Jan-14 & GC meeting \\
\hline 6-Aug-09 & GC meeting & 6-Feb-14 & GC meeting \\
\hline 3-Sep-09 & GC meeting & 6-Mar-14 & GC meeting \\
\hline 8-Oct-09 & GC meeting & 25-Mar-14 & QE amnouncement Draghi (Science Po - Paris): A consistent strategy for a sustained recovery \\
\hline 5-Nov-09 & GC meeting & 3-Apr-14 & GC meeting \\
\hline 3-Dec-09 & GC meeting, Phasing out of $6 \mathrm{~m}$ LTROs, indexation of $1 \mathrm{y}$ LTROs & 24-Apr-14 & QE amnouncement Draghi (NDL Conf - Amsterdam): Monetary policy communication in turbulent times \\
\hline 14-Jan-10 & GC meeting & 8-May-14 & GC meeting \\
\hline 4-Feb-10 & GC meeting & 5-Jun-14 & GC meeting, MRO rate decreased to $0.15 \%$, announcement of TLTROS \\
\hline 4-Mar-10 & GC meeting, Phasing out of $3 \mathrm{~m}$ LTROs, indexation of $6 \mathrm{~m}$ LTROS & 3-Jul-14 & GC meeting, details of TLTROs \\
\hline 8-Apr-10 & GC meeting & 7-Aug-14 & GC meeting \\
\hline 6-May-10 & GC meeting & 4-Sep-14 & GC meeting, $\mathrm{MRO}$ rate decreased to $0.05 \%$, announcement of $\mathrm{CCBP} 3 \& \mathrm{ABSPP}$ \\
\hline 9-May-10 & GC meeting, Securities Market Programme (SMP) & 2-Oct-14 & GC meeting, details of ABSPP CBPP3 \\
\hline 10-Jun-10 & GC meeting & 6 -Nov-14 & GC meeting \\
\hline 8-Jul-10 & GC meeting & 4-Dec-14 & GC meeting, introduction of the QE-PSPP - Draghi: 'More stimulus is likely on the way, but the final decision wont be taken until early next year' \\
\hline 28-Jul-10 & Collateral rules tightened, revised haircuts & 22-Jan-15 & GC meeting, amnouncement of PSPP \\
\hline 5-Aug-10 & GC meeting & 9-Mar-15 & start of the PSPP purchases \\
\hline 2-Sep-10 & GC meeting & 5-Mar-15 & GC meeting \\
\hline 7-Oct-10 & GC meeting & 15-Apr-15 & GC meeting \\
\hline 4-Nov-10 & GC meeting & 3-Jum-15 & GC meeting \\
\hline 2-Dec-10 & GC meeting & 16-Jul-15 & GC meeting \\
\hline 13-Jan-11 & GC meeting & 3-Sep-15 & GC meeting, possible extension of QE program (Draghi) \\
\hline 3-Feb-11 & GC meeting & 22-Oct-15 & GC meeting \\
\hline 3-Mar-11 & GC meeting, FRFA extended to July 2011 & 03-Nov-15 & Draghi: willing and able to act by using all instruments within its mandate \\
\hline 7-Apr-11 & GC meeting, MRO increased to $1.25 \%$ & 03-Dec-15 & GC meeting \\
\hline 5 -May-11 & GC meeting & 21-Jan-16 & GC meeting \\
\hline 9-Jun-11 & GC meeting & 10-Mar-16 & GC meeting \\
\hline 7-Jul-11 & GC meeting, MRO increased to $1.50 \%$ & 21-Apr-16 & GC meeting \\
\hline 4.Aug-11 & GC meeting, SMP covers Spain and Italy & 2-Jun-16 & GC meeting \\
\hline 7-Aug-11 & SMP on Italy and Spain acknowledged by ECB & 21-Jul-16 & GC meeting \\
\hline 8-Sep-11 & GC meeting & 8-Sep-16 & GC meeting \\
\hline 6-Oct-11 & GC meeting, CBPP2 launched & 20-Oct-16 & GC meeting \\
\hline 3-Nov-11 & GC meeting, MRO decreased to $1.25 \%$ & 8-Dec-16 & GC meeting \\
\hline 8-Dec-11 & GC meeting, Two 3-year LTROs, reserve ratio to $1 \%$, MRO rate decreased to $1 \%$ & 19-Jan-17 & GC meeting \\
\hline 21-Dec-11 & Results of first 3-year LTRO & & \\
\hline
\end{tabular}


Table 14: ECB Monetary Policy Days (January 1999 - July 2008).

The table reports a list of press releases following the ECB GC meetings.

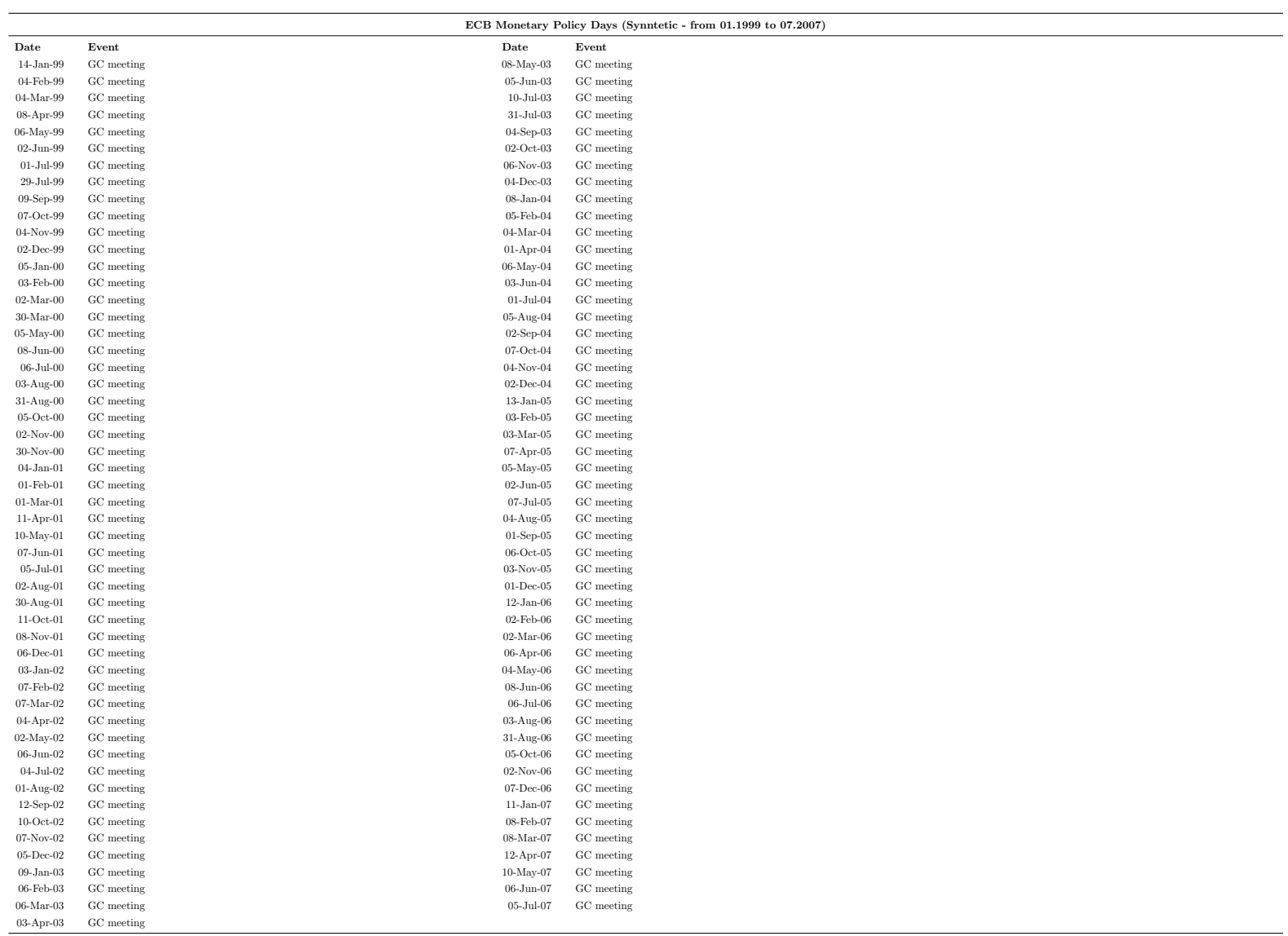


Table 15: FED Monetary Policy Days (August 2008 - February 2017).

The table reports a detailed list of regular and extraordinary press releases from the FED having potential monetary policy implications.

\begin{tabular}{|c|c|c|c|}
\hline \multicolumn{4}{|c|}{ Fed Monetary Policy Days (Detailed - from 10.2008 onwards) } \\
\hline Date & Event & Date & Event \\
\hline 8-Oct-08 & Joint Statement by Central Banks, FOMC decrease fed funds rate by $0.5 \% \mathrm{pp}$ to $1.50 \%$ & 24-Oct-12 & FOMC meeting \\
\hline 29-Oct-08 & FOMC meeting & 12-Dec-12 & FOMC meeting \\
\hline 25-Nov-08 & Fed announces results of auction of $\$ 150$ billion in 13-day credit & 30-Jan-13 & FOMC meeting \\
\hline 1-Dec-08 & Federal Reserve announces results of auction of $\$ 150$ billion in 84 -day credit & 20-Mar-13 & FOMC meeting - Bernanke warns of 'premature tightening' in monetary policy (taper tantrum) \\
\hline 16-Dec-08 & FOMC meeting & 1-May-13 & FOMC meeting \\
\hline 28-Jan-09 & FOMC meeting & 22-May-13 & Bernanke warns of 'premature tightening' in monetary policy (taper tantrum) \\
\hline 18-Mar-09 & FOMC meeting & 19-Jun-13 & FOMC meeting - Bernanke warns of taper tantrum again \\
\hline 29-Apr-09 & FOMC meeting & 31-Jul-13 & FOMC meeting \\
\hline 24-Jun-09 & FOMC meeting & 18-Sep-13 & FOMC meeting \\
\hline 12-Aug-09 & FOMC meeting & 16-Oct-13 & unscheduled FOMC meeting \\
\hline 23-Sep-09 & FOMC meeting & 30-Oct-13 & FOMC meeting \\
\hline 4-Nov-09 & FOMC meeting & 18-Dec-13 & FOMC meeting \\
\hline 16-Dec-09 & FOMC meeting & 29-Jan-14 & FOMC meeting \\
\hline 27-Jan-10 & FOMC meeting & 4-Mar-14 & unscheduled FOMC meeting \\
\hline 16-Mar-10 & FOMC meeting & 19-Mar-14 & FOMC meeting \\
\hline 28-Apr-10 & FOMC meeting & 30-Apr-14 & FOMC meeting \\
\hline 9-May-10 & unscheduled FOMC meeting & 18-Jun-14 & FOMC meeting \\
\hline 23-Jun-10 & FOMC meeting & 15-Jul-14 & Semiannual Monetary Policy Report to the Congress \\
\hline 10-Aug-10 & FOMC meeting & 30-Jul-14 & FOMC meeting \\
\hline 27-Aug-10 & Ben Bernanke Jackson Hole speech & 22-Aug-14 & Janet Yellen Jackson Hole speech \\
\hline 21-Sep-10 & FOMC meeting & 17-Sep-14 & FOMC meeting \\
\hline 15-Oct-10 & unscheduled FOMC meeting & 29-Oct-14 & FOMC meeting \\
\hline 3-Nov-10 & FOMC meeting & 17-Dec-14 & FOMC meeting \\
\hline 14-Dec-10 & FOMC meeting & 28-Jan-15 & FOMC meeting \\
\hline 26-Jan-11 & FOMC meeting & 24-Feb-15 & Semiannual Monetary Policy Report to the Congress \\
\hline 15-Mar-11 & FOMC meeting & 18-Mar-15 & FOMC meeting \\
\hline 27-Apr-11 & FOMC meeting & 29-Apr-15 & FOMC meeting \\
\hline 22-Jun-11 & FOMC meeting & 17-Jun-15 & FOMC meeting \\
\hline 1-Aug-11 & unscheduled FOMC meeting & 29-Jul-15 & FOMC meeting \\
\hline 9-Aug-11 & FOMC meeting & 17 -Sep-15 & FOMC meeting \\
\hline 26-Aug-11 & Ben Bernanke Jackson Hole speech & 28-Oct-15 & FOMC meeting \\
\hline 21-Sep-11 & FOMC meeting & 16-Dec-15 & FOMC meeting \\
\hline 2-Nov-11 & FOMC meeting & 27-Jan-16 & FOMC meeting \\
\hline 28-Nov-11 & unscheduled FOMC meeting & 16-Mar-16 & Press Conference \\
\hline 13-Dec-11 & FOMC meeting & $27-\mathrm{Apr}-16$ & FOMC meeting \\
\hline 25-Jan-12 & FOMC meeting & 15-Jun-16 & Press Conference \\
\hline 13-Mar-12 & FOMC meeting & 27-Jul-16 & FOMC meeting \\
\hline
\end{tabular}


Table 16: FED Monetary Policy Days (January 1999 - July 2008).

The table reports a list of press releases following the FOMC meetings.

\begin{tabular}{|c|c|c|c|}
\hline \multicolumn{4}{|c|}{ Fed Monetary Policy Days (Synntetic - from 05.1999 to 10.2008 ) } \\
\hline Date & Event & Date & Event \\
\hline 30-Mar-99 & FOMC meeting & 28-Jan-04 & FOMC meeting \\
\hline 18-May-99 & FOMC meeting & 11-Feb-04 & FOMC meeting \\
\hline 30-Jun-99 & FOMC meeting & 16-Mar-04 & FOMC meeting \\
\hline 22-Jul-99 & FOMC meeting & 04-May-04 & FOMC meeting \\
\hline 24-Aug-99 & FOMC meeting & 30-Jun-04 & FOMC meeting \\
\hline 05-Oct-99 & FOMC meeting & 20-Jul-04 & FOMC meeting \\
\hline 16-Nov-99 & FOMC meeting & 10-Aug-04 & FOMC meeting \\
\hline 21-Dec-99 & FOMC meeting & 21-Sep-04 & FOMC meeting \\
\hline 02-Feb-00 & FOMC meeting & 10-Nov-04 & FOMC meeting \\
\hline 17-Feb-00 & FOMC meeting & 14-Dec-04 & FOMC meeting \\
\hline 21-Mar-00 & FOMC meeting & 02-Feb-05 & FOMC meeting \\
\hline 16 -May-00 & FOMC meeting & 16 -Feb-05 & FOMC meeting \\
\hline 28-Jun-00 & FOMC meeting & 22-Mar-05 & FOMC meeting \\
\hline 20-Jul-00 & FOMC meeting & 03-May-05 & FOMC meeting \\
\hline 22-Aug-00 & FOMC meeting & 30-Jun-05 & FOMC meeting \\
\hline 03-Oct-00 & FOMC meeting & 20-Jul-05 & FOMC meeting \\
\hline 15-Nov-00 & FOMC meeting & 09-Aug-05 & FOMC meeting \\
\hline 19-Dec-00 & FOMC meeting & 20-Sep-05 & FOMC meeting \\
\hline 03-Jan-01 & FOMC meeting & 01-Nov-05 & FOMC meeting \\
\hline 31-Jan-01 & FOMC meeting & 13-Dec-05 & FOMC meeting \\
\hline 13-Feb-01 & FOMC meeting & 31-Jan-06 & FOMC meeting \\
\hline 20-Mar-01 & FOMC meeting & 15-Feb-06 & FOMC meeting \\
\hline 11-Apr-01 & FOMC meeting & 28-Mar-06 & FOMC meeting \\
\hline 18-Apr-01 & FOMC meeting & 10-May-06 & FOMC meeting \\
\hline 15-May-01 & FOMC meeting & 29-Jun-06 & FOMC meeting \\
\hline 27-Jun-01 & FOMC meeting & 19-Jul-06 & FOMC meeting \\
\hline 18-Jul-01 & FOMC meeting & 08-Aug-06 & FOMC meeting \\
\hline 21-Aug-01 & FOMC meeting & 20-Sep-06 & FOMC meeting \\
\hline 13-Sep-01 & FOMC meeting & 25-Oct-06 & FOMC meeting \\
\hline 17-Sep-01 & FOMC meeting & 12-Dec-06 & FOMC meeting \\
\hline 02-Oct-01 & FOMC meeting & 31-Jan-07 & FOMC meeting \\
\hline 06-Nov-01 & FOMC meeting & 14-Feb-07 & FOMC meeting \\
\hline 11-Dec-01 & FOMC meeting & 21-Mar-07 & FOMC meeting \\
\hline 30-Jan-02 & FOMC meeting & 09-May-07 & FOMC meeting \\
\hline 27-Feb-02 & FOMC meeting & 28-Jun-07 & FOMC meeting \\
\hline 19-Mar-02 & FOMC meeting & 18-Jul-07 & FOMC meeting \\
\hline 07-May-02 & FOMC meeting & 07-Aug- 07 & FOMC meeting \\
\hline 26-Jun-02 & FOMC meeting & 10-Aug-07 & FOMC meeting \\
\hline 16-Jul-02 & FOMC meeting & 16-Aug-07 & FOMC meeting \\
\hline 13-Aug-02 & FOMC meeting & 18-Sep-07 & FOMC meeting \\
\hline 24-Sep-02 & FOMC meeting & 31-Oct-07 & FOMC meeting \\
\hline 06-Nov-02 & FOMC meeting & 06-Dec-07 & FOMC meeting \\
\hline 10-Dec-02 & FOMC meeting & 11-Dec-07 & FOMC meeting \\
\hline 29-Jan-03 & FOMC meeting & 09-Jan-08 & FOMC meeting \\
\hline 11-Feb-03 & FOMC meeting & 21-Jan-08 & FOMC meeting \\
\hline 18-Mar-03 & FOMC meeting & 30-Jan-08 & FOMC meeting \\
\hline 25-Mar-03 & FOMC meeting & 27-Feb-08 & FOMC meeting \\
\hline 01-Apr-03 & FOMC meeting & 10-Mar-08 & FOMC meeting \\
\hline 08-Apr-03 & FOMC meeting & 18-Mar-08 & FOMC meeting \\
\hline 16-Apr-03 & FOMC meeting & 30-Apr-08 & FOMC meeting \\
\hline 06-May-03 & FOMC meeting & 25-Jun- 08 & FOMC meeting \\
\hline 25-Jun-03 & FOMC meeting & 15-Jul-08 & FOMC meeting \\
\hline 15-Jul-03 & FOMC meeting & 24-Jul-08 & FOMC meeting \\
\hline 12-Aug-03 & FOMC meeting & 05-Aug- 08 & FOMC meeting \\
\hline 15-Sep-03 & FOMC meeting & 16-Sep-08 & FOMC meeting \\
\hline 16-Sep-03 & FOMC meeting & 29-Sep-08 & FOMC meeting \\
\hline 28-Oct-03 & FOMC meeting & 07-Oct-08 & FOMC meeting \\
\hline 09-Dec-03 & FOMC meeting & & \\
\hline
\end{tabular}


A.3 Monetary policy surprise 


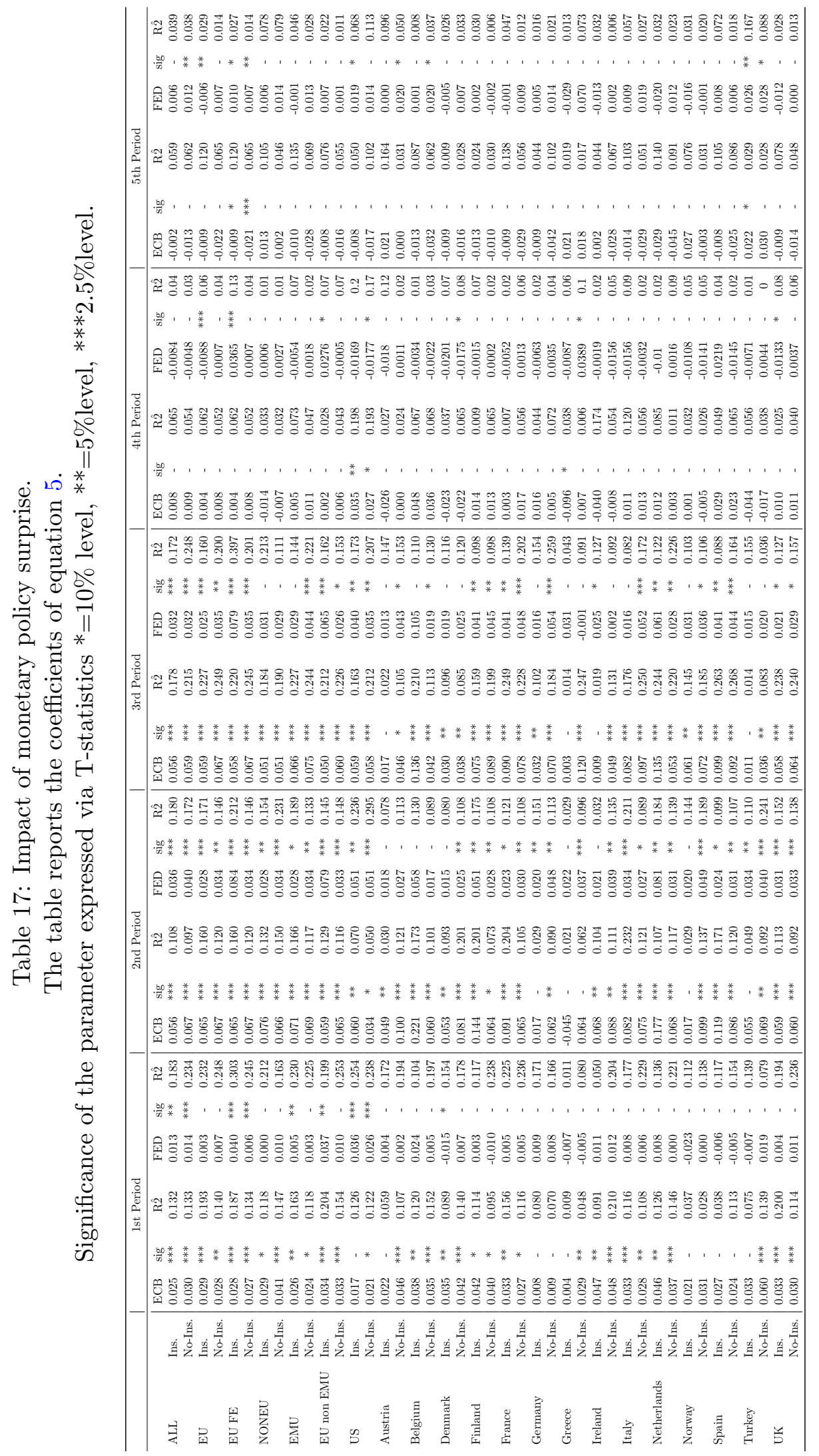




\section{A.4 Monetary policy surprise - net effects on stock prices}

Table 18: Monetary policy surprise - net effects on stock prices.

Tabular representation of the interactions among monetary policy surprise (first principal component on the interest rates term structure), the sign of the coefficients associated to them via OLS regression (ref. equation 5), and the net impacts on stock prices. Significance of the parameter expressed via T-statistics $*=10 \%$ level, $* *=5 \%$ level, $* * * 2.5 \%$ level.

\begin{tabular}{c|c|cc|c}
\hline & PCA & \multicolumn{2}{|c}{ OLS coefficient } & Effect on the \\
Period & Sign & Sign & Significance & Stock Returns \\
\hline 1 & - & + & $* * *$ & - \\
2 & - & + & $* * *$ & - \\
3 & + & + & $* * *$ & + \\
4 & + & + &. &. \\
5 & - & - &. &. \\
\hline
\end{tabular}




\section{A.5 Monetary policy surprise - sensitivity to different time windows}

Table 19: Impact of ECB monetary policy surprise - sensitivity to time windows. The table reports the impact of ECB monetary policy interventions estimated via equation 5 applying three time windows. Significance of the parameter expressed via T-statistics $*=10 \%$ level, ${ }^{* *}=5 \%$ level, $* * * 2.5 \%$ level.

\begin{tabular}{|c|c|c|c|c|c|c|}
\hline \multicolumn{7}{|c|}{ Period 1 - 6.9.04 - 15.6.08 } \\
\hline \multirow[b]{2}{*}{ Variable } & \multicolumn{2}{|c|}{-2 days, announcement day } & \multicolumn{2}{|c|}{-1 day, announcement day, +1 day } & \multicolumn{2}{|c|}{ 'announcement day, +2 days } \\
\hline & ECB & Sig & ECB & Sig & ECB & Sig \\
\hline $\mathrm{EU}$ & 0.029 & $* * *$ & 0.017 & $*$ & 0.016 & - \\
\hline EMU & 0.026 & $* *$ & 0.014 & - & 0.011 & - \\
\hline EU NON EMU & 0.034 & $* * *$ & 0.023 & $* *$ & 0.023 & $* *$ \\
\hline NO EU & 0.029 & $*$ & 0.022 & - & 0.019 & - \\
\hline US & 0.017 & - & 0.010 & - & 0.014 & - \\
\hline
\end{tabular}

\begin{tabular}{|c|c|c|c|c|c|c|}
\hline \multicolumn{7}{|c|}{ Period 2 - 16.6.08 - 31.8.10 } \\
\hline \multirow[b]{2}{*}{ Variable } & \multicolumn{2}{|c|}{-2 days, announcement day } & \multicolumn{2}{|c|}{-1 day, announcement day, +1 day } & \multicolumn{2}{|c|}{ 'announcement day, +2 days } \\
\hline & ECB & Sig & ECB & Sig & ECB & Sig \\
\hline $\mathrm{EU}$ & 0.065 & $* * *$ & 0.054 & $* * *$ & 0.084 & $* * *$ \\
\hline EMU & 0.071 & $* * *$ & 0.057 & $* * *$ & 0.094 & $* * *$ \\
\hline EU NON EMU & 0.059 & $* * *$ & 0.051 & $* * *$ & 0.073 & $* * *$ \\
\hline NO EU & 0.076 & $* * *$ & 0.072 & $* * *$ & 0.102 & $* * *$ \\
\hline US & 0.060 & $* *$ & 0.055 & $*$ & 0.086 & $* * *$ \\
\hline
\end{tabular}

\begin{tabular}{|c|c|c|c|c|c|c|}
\hline \multicolumn{7}{|c|}{ Period 3 - 1.9.10 - 30.6.12 } \\
\hline \multirow[b]{2}{*}{ Variable } & \multicolumn{2}{|c|}{-2 days, announcement day } & \multicolumn{2}{|c|}{-1 day, announcement day, +1 day } & \multicolumn{2}{|c|}{ 'announcement day, +2 days } \\
\hline & ECB & Sig & ECB & Sig & ECB & Sig \\
\hline $\mathrm{EU}$ & 0.059 & $* * *$ & 0.052 & $* * *$ & 0.055 & $* * *$ \\
\hline EMU & 0.066 & $* * *$ & 0.058 & $* * *$ & 0.061 & $* * *$ \\
\hline EU NON EMU & 0.050 & $* * *$ & 0.045 & $* * *$ & 0.048 & $* * *$ \\
\hline NO EU & 0.051 & $* * *$ & 0.056 & $* * *$ & 0.061 & $* * *$ \\
\hline US & 0.059 & $* * *$ & 0.056 & $* * *$ & 0.062 & $* * *$ \\
\hline \multicolumn{7}{|c|}{ Period $4-1.7 .12-31.12 .13$} \\
\hline & \multicolumn{2}{|c|}{-2 days, announcement day } & \multicolumn{2}{|c|}{-1 day, announcement day, +1 day } & \multicolumn{2}{|c|}{ 'announcement day, +2 days } \\
\hline Variable & ECB & Sig & ECB & Sig & ECB & Sig \\
\hline $\mathrm{EU}$ & 0.004 & - & 0.030 & $*$ & 0.027 & - \\
\hline EMU & 0.005 & - & 0.035 & * & 0.035 & $*$ \\
\hline EU NON EMU & 0.002 & - & 0.022 & - & 0.015 & - \\
\hline NO EU & -0.014 & - & -0.005 & - & -0.005 & - \\
\hline US & 0.035 & $* *$ & 0.053 & $* * *$ & 0.049 & $* * *$ \\
\hline \multicolumn{7}{|c|}{ Period 5 - 1.1.14 - 20.2.17 } \\
\hline & \multicolumn{2}{|c|}{-2 days, announcement day } & \multicolumn{2}{|c|}{-1 day, announcement day, +1 day } & \multicolumn{2}{|c|}{ 'announcement day, +2 days } \\
\hline Variable & ECB & Sig & ECB & Sig & ECB & Sig \\
\hline $\mathrm{EU}$ & -0.009 & - & 0.004 & - & 0.004 & - \\
\hline EMU & -0.010 & - & 0.014 & - & 0.010 & - \\
\hline EU NON EMU & -0.008 & - & -0.006 & - & -0.003 & - \\
\hline NO EU & 0.013 & - & 0.013 & - & 0.012 & - \\
\hline US & -0.008 & - & 0.037 & - & 0.038 & - \\
\hline
\end{tabular}




\section{A.6 Analysis of determinants - Correlation matrix}

Table 20: Balance Sheet Indices - Correlation Matrix.

The table reports correlations among the balance sheet indices used in the logit regression(ref. equation 8).

\begin{tabular}{lcccccccc}
\hline & $(1)$ & $(2)$ & $(3)$ & $(4)$ & $(5)$ & $(6)$ & $(7)$ & $(8)$ \\
\hline (1) Total Assets (Ln) & 1.000 & & & & & & & \\
(2) Fixed Income Assets & 0.334 & 1.000 & & & & & & \\
(3) Equity Assets & -0.114 & -0.450 & 1.000 & & & & & \\
(4) Cash \& Equivalent & -0.171 & 0.057 & -0.007 & 1.000 & & & & \\
(5) Non-Insurance Activities & 0.062 & -0.434 & 0.321 & 0.134 & 1.000 & & & \\
(6) Life Business & 0.270 & -0.325 & 0.616 & 0.010 & 0.589 & 1.000 & & \\
(7) Unit-Linked Business & 0.045 & -0.330 & 0.530 & 0.072 & 0.452 & 0.754 & 1.000 & \\
(8) Dividend Payout & -0.161 & -0.171 & 0.102 & 0.134 & -0.076 & -0.015 & -0.004 & 1.000 \\
\hline
\end{tabular}




\section{References}

Albizzati, M. and Geman, H. (1994). Interest rate risk management and valuation of the surrender option in life insurance policies. Journal of Risk and Insurance, 61(2):616637.

Ampudia, M. and Van-den Heuvel, S. (2017). Monetary policy and bank equity values in a time of low interest rates. Working paper.

Arseneau, D. (2017). How would u.s. banks fare in a negative interest rate environment? Finance and Economics Discussion Series, Board of Governors of the Federal Reserve System (U.S.), 2017-30.

Banerjee, R., Latto, D., and McLaren, N. (2014). Using changes in auction maturity sectors to help identify the impact of qe on gilt yields. Economic Journal, 124:453-479.

Berdin, E. and Grndl, H. (2015). The effect of a low interest rate environment on life insurers. The Geneva Papers on Risk and Insurance-Issues and Practice, 40(3):385-415.

Bernanke, B. S. and Kuttner, K. (2005). What explains the stock market's reaction to federal reserve policy? The Geneva Papers on Risk and Insurance-Issues and Practice, 60:1221-1257.

Briciu, L. and Lisi, G. (2015). An event study analysis of ecb balance sheet policies since october 2008. European Union Economic Brief, 1.

Chen, H., Curdina, V., and Ferrero, A. (2012). The macroeconomic effect of large-scale asset purchase programmes. Economic Journal, 122:289-315.

Chung, H., Laforte, J., Reifschneider, D., and Williams, J. (2010). Have we underestimated the likelihood and severity of zero lower bound events? Journal of Money, Credit and Banking, 44:47-82.

Cook, T. and Hahn, T. (1998). The effect of changes in the federal funds rate target on market interest rates in the 1970s. Journal of Monetary Economics, 24:331-351.

D'Amico, S., English, W., Lopez-Salido, D., and Nelson, E. (2012). The federal reserve's largescale asset purchase programmes: Rationales and effects. Economic Journal of Finance, 122:415-446.

Deutsche Bundesbank (2013). Financial stability review 2013. Technical report.

ECB (2015). Ecb announces expanded asset purchase programme.

Ehrmann, M., Fratzscher, M., Guerkanyak, R., and Swanson, E. (2011). Convergence and anchoring of yield curves in the euro area. Review of Economics and Statistics, 93:350-364.

EIOPA (2013). Financial stability report, second half year report 2013.

EIOPA (2014). Financial stability report, second half year report 2014.

EIOPA (2015). Financial stability report, second half year report 2015. 
European Parliament and of the Council of 25 (2009). Directive 2009/138/EC on the Taking-Up and Pursuit of the Business of Insurance and Reinsurance (Solvency II).

Gambacorta, L., H. B. and Peersman, G. (2014). The effectiveness of unconventional monetary policy at the zero lower bound: A cross-country analysis. Journal of Money, Credit and Banking, 46:615-642.

Gatzert, N. (2008). Asset management and surplus distribution strategies in life insurance: An examination with respect to risk pricing and risk measurement. Insurance: Mathematics and Economics, 42(2):839849.

Grosen, A. and Lchte Jrgensen, P. (2000). Fair valuation of life insurance liabilities: the impact of interest rate guarantees, surrender options, and bonus policies. Insurance: Mathematics and Economics, 26(1):3757.

Holsboer, J. H. (2000). The impact of low interest rates on insurers. Geneva Papers on Risk and Insurance: Issues and Practice, 25(1):38-58.

IAIS (2016). Global systemically important insurers: Updated assessment methodology.

Ippolito, F., Ozdagli, A. K., and Perez, A. (2015). Is bank debt special for the transmission is bank debt special for the transmission. Unpublished manuscript. Universitat Pompeu Fabra.

Joyce, M., Lasosa, A., Stevens, I., and Tong, M. (2011). The financial market impact of quantitative easing in the united kingdom. International Journal of Central Banking, 7:113161.

Kapetanios, G., Haroon, I., and Theodoridis, K. (2012). Assessing the economy-wide effects of quantitative easing. International Journal of Central Banking, 122:316-347.

King, R. G., Plosser, C., Stock, J., and Watson, M. (1991). Stochastic trends and economic fluctuations. American economic Review, 81:819-840.

Kling, A., R. A. and Ru, J. (2007a). The impact of surplus distribution on the risk exposure of with profit life insurance policies including interest rate guarantees. Journal of Risk and Insurance, 74(3):571589.

Kling, A., R. A. and Ru, J. (2007b). The interaction of guarantees, surplus distribution, and asset allocation in with-profit life insurance policies. Insurance: Mathematics and Economics, 40(1):164178.

Krishnamurthy, A. and Vissing-Jorgensen, A. (2011). The effects of quantitative easing on long-term interest rates. Brookings Papers on Economic Activity, 2:215-265.

Li, C. and Wei, M. (2013). Term structure modelling with-supply factors and the federal reserve's large-scale asset purchase programs. International Journal of Central Banking, 9:339. 
Mackinlay, A. (1997). Event studies in economics and finance. Journal of Economic Literature, $35: 13-39$.

Pericoli, M. and Veronese, G. (2016). Monetary policy surprises and channels of transmission. Working Paper - Banca d'Italia.

Rigobon, R. (2003). Identification through heteroskedasticity. The review of Economics and stasistics, 85(4):777-792.

Rogers, J. H., Scotti, C., and Wright, J. H. (2014). Evaluating asset-market effects of unconventional monetary policy: A cross-country comparison. International Finance Discussion Papers, 1101.

Wedow, M. and Kablau, A. (2011). Gauging the impact of a low-interest rate environment on german life insurers. Deutsche Bundesbank Discussion Papers, 02. 


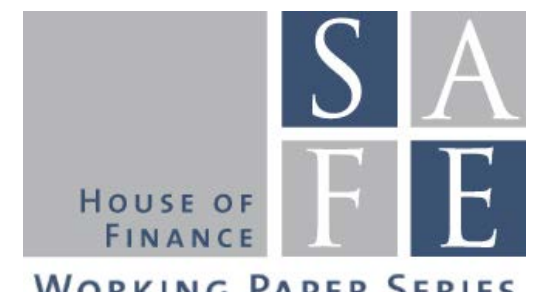

WORKING PAPER SERIES

\section{Recent Issues}

No. 203 Florian Hett, Felix Schmidt

No. 202 Tobias H. Tröger

No. 201 Dirk Krueger, Alexander Ludwig

No. 200 Nils Grevenbrock, Max Groneck, Alexander Ludwig, Alexander Zimper

No. 199 Tobias H. Tröger

No. 198 Henning Hesse, Boris Hofmann, James Weber

No. 197 Benjamin Clapham, Peter Gomber, Martin Haferkorn, Paul Jentsch, Sven Panz

No. 196 Benjamin Clapham, Peter Gomber, Sven Panz

No. 195 Benjamin Clapham, Peter Gomber, Martin Haferkorn, Sven Panz

No. 194 Baptiste Massenot

No. 193 Mario Bellia, Roberto Panzica, Loriana Pelizzon, Tuomas Peltonen

No. 192 Vincenzo Pezone

No. 191 Julia Hirsch, Uwe Walz

No. 190 Vanya Horneff, Raimond Maurer, Olivia S. Mitchell
Pushing Through or Slacking Off? Heterogeneity in the Reaction to Rank Feedback

Germany's Reluctance to Regulate Related Party Transactions

Optimal Taxes in the OLG Model with Uninsurable Idiosyncratic Income Risk

Cognition, Optimism and the Formation of Age-Dependent Survival Beliefs

Regulation of Crowdfunding in Germany

The Macroeconomic Effect of Asset Purchases Revisited

Circuit Breakers - A Survey among International Trading Venues

Coordination of Circuit Breakers? Volume Migration and Volatility Spillover in Fragmented Markets

Managing Excess Volatility: Design and Effectiveness of Circuit Breakers

A Business Cycle Model with Neuroeconomic Foundations

The Demand for Central Clearing: To Clear or Not to Clear, That is the Question

The Real Effects of Judicial Enforcement: Evidence from Italy

Financial constraints, newly founded firms and the financial crisis

How Persistent Low Expected Returns Alter Optimal Life Cycle Saving, Investment, and Retirement Behavior 